\title{
Sedimentology and Geochemical Evaluation of Lignite-Argillite Sequences in a Named Basin in Bali Nyonga, Northwest, Cameroon
}

\author{
Roger Ngong Ngia ${ }^{*}$, Christopher M. Agyingi ${ }^{*}$, Josepha Foba-Tado², \\ Germain M. M. Mboudou', Anita Nshukwi', Victorine N. Beckley ${ }^{2}$ \\ ${ }^{1}$ Department of Geology, University of Buea, Buea, Cameroon \\ ${ }^{2}$ Department of Chemistry, University of Buea, Buea, Cameroon \\ Email: "ngongrogerngia@yahoo.com, ${ }^{*}$ cmagyingi@gmail.com
}

Received 6 July 2015; accepted 28 August 2015; published 31 August 2015

Copyright (C) 2015 by authors and Scientific Research Publishing Inc.

This work is licensed under the Creative Commons Attribution International License (CC BY). http://creativecommons.org/licenses/by/4.0/

(c) (i) Open Access

\section{Abstract}

The sedimentology and geochemistry (major and trace element compositions) of lignite and argillite (carbonaceous shale and claystone) sequences in a Basin in Bali Nyonga, west of the Bamenda Mountain have been investigated to determine their sequences and the prevailing environmental conditions which control their formation. Ten representative samples were obtained from trenches, pits, and river and stream valleys in the study area. These samples and their ashes were subsequently examined using X-ray fluorescence spectrometry (XRF), inductively coupled plasma spectrometry (ICP), and X-ray diffraction analysis (XRD). The geochemical results revealed that the lithophile, chalcophile and siderophile elements were dominantly epigenetic in origin, mainly from detrital sources supported by high silica and alumina concentrations in all the samples. The mineral phases identified were quartz, kaolinite, illite, pyrite, hematite, and minor phases of feldspars, pseudorutile. The relatively high silica $(54.10 \mathrm{wt} \%)$ and alumina contents $(27.77 \mathrm{wt} \%)$ in these samples can be explained by high detrital input during peat formation. The low contents of MgO and $\mathrm{CaO}$ in the analysed samples agree very much with the continental setting of the peat formating basin. A clayey microband derived from alkaline volcanic ashes was identified in the lignite and the dominant composition of these clayey microbands was mixed-layer clay minerals of illite and kaolinte, which were interlayered with organic bands. The modes of occurrence of ash bands indicated that the volcanic activities were characterized by multiple eruptions, short time interval and small scale for each eruption during peat accumulation. The ratios of redox-sensitive trace element $(\mathrm{V} / \mathrm{Cr}$ versus $\mathrm{Ni} / \mathrm{Co}$ and $\mathrm{V} / \mathrm{V}+\mathrm{Ni}$ versus $\mathrm{Ni} / \mathrm{Co}$ ), $\mathrm{Sr} / \mathrm{Ba}$, and major oxides ratio (CaO + $\mathrm{MgO}$ $\left.+\mathrm{Fe}_{2} \mathrm{O}_{3}\right) /\left(\mathrm{SiO}_{2}+\mathrm{Al}_{2} \mathrm{O}_{3}\right)$ from the analysed samples from Bali Nyonga indicate a terrestrial, reductive (oxic), littoral to brackish water environmental conditions which are characteristics of paludal-lacustrine basin that is filled by Tertiary volcanic materials.

${ }^{*}$ Corresponding authors.

How to cite this paper: Ngia, R.N., Agyingi, C.M., Foba-Tado, J., Mboudou, G.M.M., Nshukwi, A. and Beckley, V.N. (2015) Sedimentology and Geochemical Evaluation of Lignite-Argillite Sequences in a Named Basin in Bali Nyonga, Northwest, Cameroon. International Journal of Geosciences, 6, 917-937. http://dx.doi.org/10.4236/ijg.2015.68074 


\section{Keywords}

\section{Lignite, Bali Nyonga, Argillite, Clay Minerals, Cameroon Volcanic Line (CVL), Lacustrine Basin}

\section{Introduction}

Lithologically, this basin consists of a sequence of conglomerate, fine to meduim-grained sandstone, argillite (claystone and carbonaceous shale), beds within which are continental lignite seam intercalations. Coal is a highly heterogeneous organoclastic sedimentary rock consisting of a variety of humified plant-derived organic matter or debris which is deposited in layers, undergoes coalification and may have vertical and lateral facies changes [1]. These changes reflect variation in vegetation type, climate, clastic input, plant decomposition rates, bacteria and fungi effect on dead plants. The lignite of Bali-Nyonga originated as a wet spongy peat deposited in a swamp, (stable, intermountain subsiding swamp) in a warm and humid climate, which after burial undergo compaction and diagenesis by increasing temperature, pressure etc. Therefore, the properties of this lignite are somehow a reflection of the original depositional environment and the diagenetic history of the plant remains and associated sediments [1]. Lignite has both organic and inorganic fractions [2]. The kind and contents of inorganic matter significantly vary in lignite depending on the different peat-forming environment. This variation might be striking also from place to place within the same lignite deposit, depending primarily on the local geological and climatic conditions, which prevailed in the peat-forming palaeo environments [3] [4]. A range of inorganic mineral constituents broadly referred to as "mineral matter" [2] make a bulk of the samples from Bali. Most elements contained in the lignite and carbonaceous shales showed a close association with organic matter or with the inorganic fraction and the changes in the element affinity with either the organic or inorganic fraction may occur during coalification [5]. Several researchers have attempted to study the geochemical features of trace elements contained in coal to understand and evaluate trace elements' mode of occurrence as well as their behaviour during combustion [6]-[9]. This research reveals that most of the trace elements in the lignite and argillite samples are associated with three major minerals: sulphides, clay minerals (kaolinite and illite), and feldspars. Within the peat environment, certain unstable detrital clay may undergo alteration or dissolution [10]. Other clay, such as kaolinite, may form authigenically; biogenic silica dissolves, possibly contributing to later authigenic mineralization [10] [11]. The authigenic kaolinite occurred as dirt partings and also along cleats in the lignite in this study. Claystone beds are also found in the study area to be formed from the complete alteration of volcanically-derived materials such as tuffs/ashes and breccias. The variation in the mineralogy and bulk geochemistry of lignite and argillite has been used to provide insights into the peat depositional environment and the palaeogeographical conditions as well as the provenance [12]-[14]; their results are not so different from this study. The weathering of alkaline volcanic ash/tuffs, basic and acid igneous rocks, and basement complex were the dominant factors for the enrichment of detrital inorganic inputs, responsible for the occurrence and distribution of most trace elements in the lignite and argillite samples studied.

The sedimentological and geochemical characteristics of lignite-argillite sequences in the study area are still unclear. It is at this background that this research work is to carry out the sedimentology and geochemistry (chemical composition of trace and major elements) of lignite and argillite samples from a basin in Bali-Nyonga. In this way, the prevailing geochemical environmental conditions, depositional and a stratigraphical model for the rocks will be designed and this will also aid in understanding their relationship with the volcanic rocks in this basin.

\section{Location of the Study Area and Geologic Settings}

The study area lies between longitude $9^{\circ} 59^{\prime} 9^{\prime \prime} \mathrm{E}$ to $10^{\circ} 0^{\prime} 512^{\prime \prime} \mathrm{E}$ and latitude $5^{\circ} 52^{\prime} 865^{\prime \prime} \mathrm{N}$ to $5^{\circ} 53^{\prime} 882^{\prime \prime} \mathrm{N}$ and covers a surface area of about 4.151 square kilometers (Figure 1). It is located on the western flank of the Bamenda Mountain which is one of the mountains along the Cameroon Volcanic Line (CVL). The Cameroon Volcanic Line $(\mathrm{CVL})$ is one of the major geological lineaments of the African plate and continent [15], and it is a mega volcano-tectonic structure, which is a $1600 \mathrm{~km}$ long chain of Cenozoic volcanic and sub-volcanic complexes that straddles the continent-ocean boundary and extends from the Gulf of Guinea to the interior of the Africa continent [16]. The continental sector of the CVL is represented by the major volcanic mountains in which the Bambouto Mountain and Oku massifs; of which Bamenda Mountain is part [17]. This study area constitutes a 


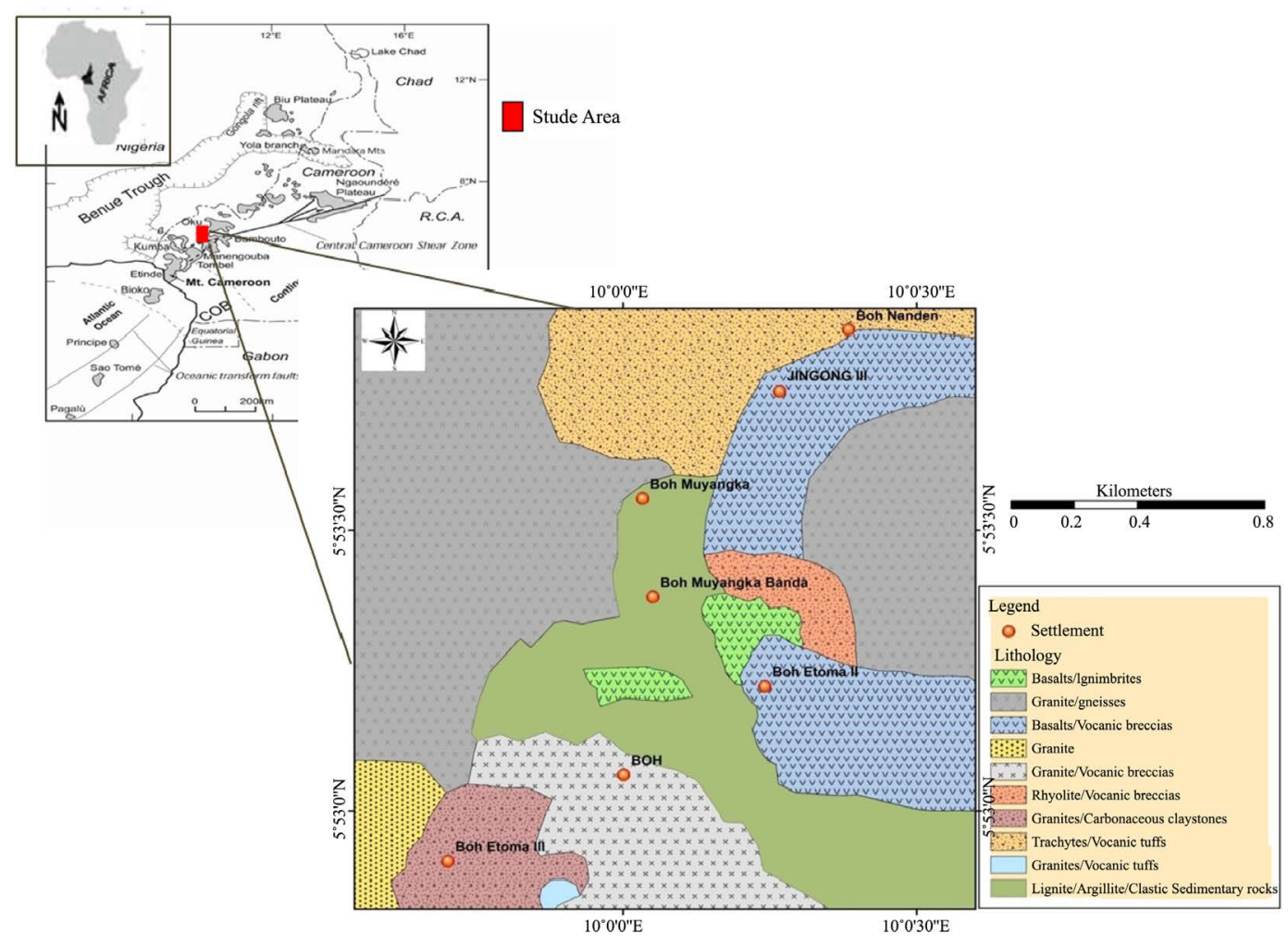

Figure 1. Location of the study area within the CVL, and simplified geologic map of the study area.

very important part of the continental sector of the CVL and lies mid-way between Bambouto in thesouth east and the Oku massif in the northwest

The Bamenda Mountain has an altitude of $2621 \mathrm{~m}$ and is characterized by two elliptical calderas: Santa-Mbu caldera $(6 \mathrm{~km}$ by $4 \mathrm{~km})$ and Lefo caldera $(4 \mathrm{~km}$ by $3 \mathrm{~km}$ ) wide [18]. The western highlands (Mount Bambouto and Bamenda Mountain) are made up of mafic and felsic lavas, with ignimbritic flow ranging from welded to non-welded brecciated rocks [19]. The volcanic of this mountain are made up mainly of trachytes, basalts, rhyolite, ignimbrites, volcanic breccias and others. These volcanic rocks are emplaced on a granitic and meta-granite basement of Pan African age [20], with extensive outcrops on the southern and north western portions of the study area. The mafic rock of the Bamenda area range from basalt to mugearite with an age $<7$ ma associated to trachytes and rhyolite whose ages are $>25$ ma [19]. [18] Studied the magnetic fabrics of pyroclasts on the Bamenda Mountain, indicated that pyroclastic currents were responsible for the volcanic pyroclastic deposits on the Mountain, with the Bambouto and Santa-Mbu calderas been the suspected sources of these massive lapilli (ash/tuff) and ignimbritic flows of the mountain and environs.

Some reconnaissance studies were carried out between the periods 1924 to 1936 on lignite during the construction of the Dschang-Bana road [21]. Isolated thin outcrops of lignite that measured about $33 \mathrm{~cm}$ in thickness were occasionally identified intercalated with carbonaceous shales in a lacustrine basin in Dschang beside Centre Climatic-Fonakeke resting on the basement complex rocks. Recent works in Ngwa (Dschang region) and environs by [22] [23] found fragmental volcano-sedimentary sequences (carbonaceous shale, thin lignite laminae and clastic sedimentary rocks) intercalating with the volcanics. In the Bamenda district lignite, argillite (carbonaceous shales and claystone) and clastic sedimentary rocks (sandstones, conglomerates etc) were found interbedded with the pyroclastic and lava flow [21]. In the sedimentary basin of Mamfe, traces of charcoal-like lignite were observed by [24].

\section{Sampling and Analytical Methods}

\subsection{Field Sampling}

Two main types of sampling were done: sub-surface rock sampling in pits and trenches and surface rock sam- 
pling on exposure and outcrops along rivers and stream valleys. A bed by bed sampling of the section in pits at Boh Muyangka (BM), Boh Muyangka-Banda (BMB) and Boh Etoma II (BEII) was carried out to collect fresh representative bulk samples from the top, middle and bottom parts of the lignite seams and argillites (carbonaceous shale, claystone) beds in these localities (Figure 2). Samples BEIIT-6, BEIIS-8, BMS-2, BEIIT-2, BMBPSb-1 and BMPSb-10 are lignite samples and samples BEIII-3, BN-3, BMBS-2 and BMPSb-6 are argillite samples, as shown in Table 1 and Table 2.

\subsection{Analytical Procedures}

Ten air-dried representative samples of lignite asnd argillite were carefully selected, packaged, labelled; and taken to the Mission de Promotion de Materiaux Locaux (MIPROMALO) laboratory in Yaounde for crushing using a jaw crusher. X-ray fluorescence (XRF), ICP and XRD analytical techniques were used to analyse for major, trace elements and mineral phases respectively. To achieve the X-ray fluorescence (XRF) analysis, the crushed samples were again powdered in an agate mortar and $0.25 \mathrm{~g}$ and taken to the Scientific Services (CC) Consulting Analytical Laboratory in South Africa. Fused glass beads made from the powdered samples were compacted within lithium metaborate or tetraborate for major elements analysis. The specimens were bombarded with high-energy X-rays which emits secondary radiation, characteristic of the elements present. A suite of major elements $\mathrm{SiO}_{2}, \mathrm{Al}_{2} \mathrm{O}_{3}, \mathrm{Fe}_{2} \mathrm{O}_{3}, \mathrm{MgO}, \mathrm{CaO}, \mathrm{Na}_{2} \mathrm{O}, \mathrm{K}_{2} \mathrm{O}, \mathrm{MnO}, \mathrm{TiO}_{2}$ and $\mathrm{P}_{2} \mathrm{O}_{5}$ (Table 1) were analysed on the whole lignite and argillite powdered fused glass beads using a Siemens SRS 303AS automatic X-ray spectrometer with $\mathrm{Rh}$ X-ray tube at $850^{\circ} \mathrm{C}$. These data was obtained in batches over a space of time and the detecting limit (concentration) of $0.001 \mathrm{wt} \%$. Loss on ignition (LOI) caused by escaping volatiles in the lignite and argillites was measured after heating to about $1050^{\circ} \mathrm{C}$.

Selected trace elements were analysed by fusion with inductively-coupled plasma (ICP) spectrometry technique in pulse counting mode (three points per peak) in the Consulting Analytical Laboratory in South Africa. Samples were mixed with a flux of lithium metaborate and lithium tetraborate and fused in an induction furnace.

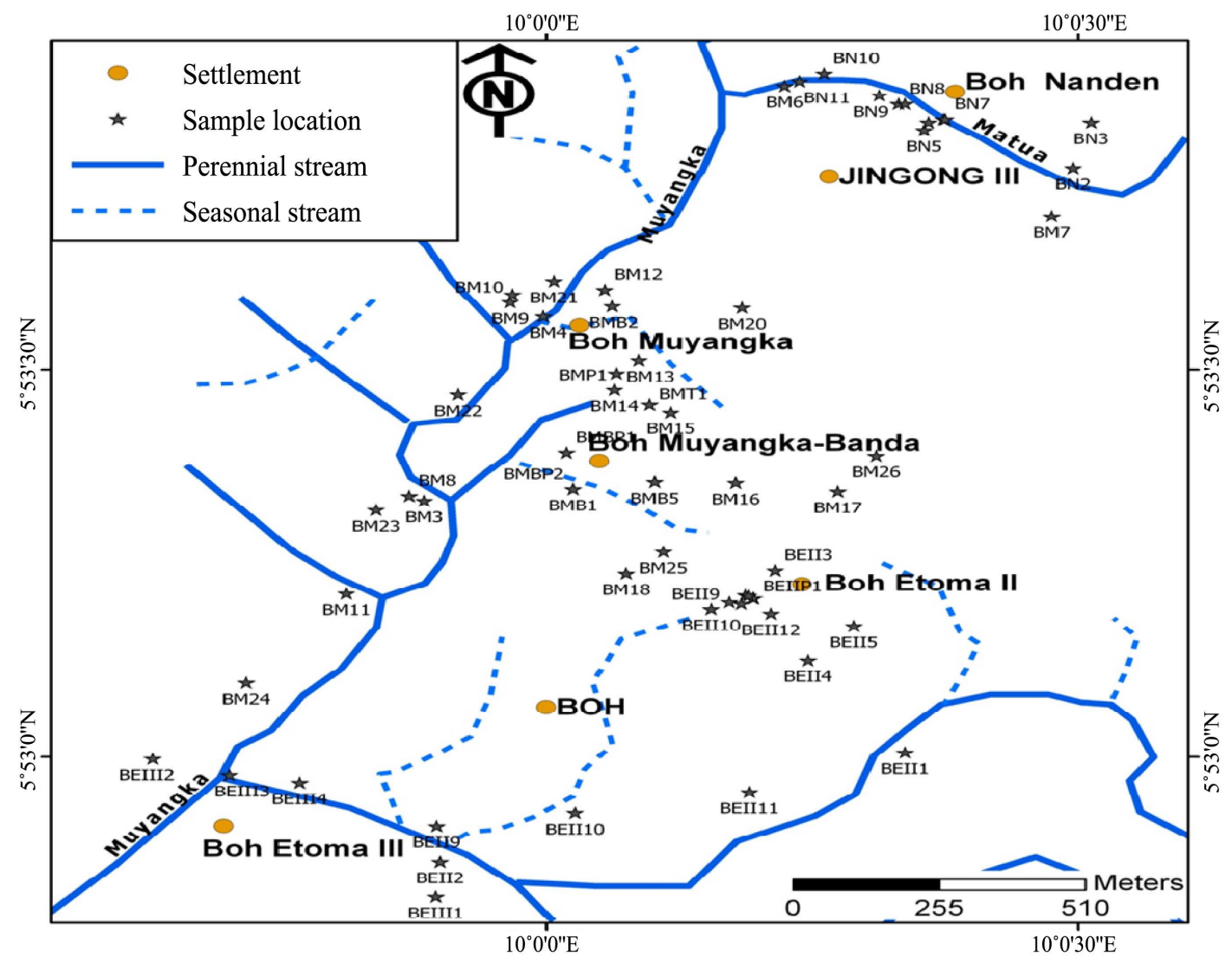

Figure 2. A simplified drainage map of the study area illustrating sample locations. 
Table 1. Major elements concentration for lignite and argillites from Bali Nyonga (values are in weight percent).

\begin{tabular}{ccccccccccccccccc}
\hline Sample & $\mathrm{Fe}_{2} \mathrm{O}_{3} \% \mathrm{MnO} \%$ & $\mathrm{Cr}_{2} \mathrm{O}_{3} \%$ & $\mathrm{~V}_{2} \mathrm{O}_{5} \%$ & $\mathrm{TiO}_{2} \%$ & $\mathrm{CaO} \%$ & $\mathrm{~K}_{2} \mathrm{O} \%$ & $\mathrm{P}_{2} \mathrm{O}_{5} \%$ & $\mathrm{SiO}_{2} \%$ & $\mathrm{Al}_{2} \mathrm{O}_{3} \%$ & $\mathrm{MgO} \% \mathrm{Na}_{2} \mathrm{O} \%$ & LOI \% & Total \\
\hline BMBS-2 & 9.99 & 0.19 & 0.01 & 0.01 & 0.78 & 0.41 & 2.00 & 0.25 & 45.36 & 22.84 & 0.00 & 0.47 & 16.78 & 99.07 \\
BE11T-2 & 1.45 & 0.01 & 0.01 & 0.01 & 0.90 & 0.16 & 1.49 & 0.13 & 48.64 & 20.81 & 0.00 & 0.25 & 25.08 & 98.93 \\
BE11T-6 & 1.13 & 0.01 & 0.01 & 0.00 & 0.87 & 0.18 & 2.03 & 0.11 & 50.44 & 18.83 & 0.00 & 0.85 & 24.66 & 99.12 \\
BMS-2 & 5.28 & 0.06 & 0.00 & 0.01 & 1.38 & 0.44 & 1.77 & 0.27 & 54.10 & 21.94 & 0.07 & 0.22 & 13.52 & 99.05 \\
BN-3 & 10.54 & 0.26 & 0.00 & 0.00 & 1.58 & 1.94 & 2.02 & 1.40 & 47.56 & 21.55 & 0.19 & 0.76 & 12.01 & 99.80 \\
BMBPSb-1 & 3.24 & 0.03 & 0.01 & 0.02 & 0.96 & 0.18 & 1.26 & 0.27 & 44.17 & 27.77 & 0.00 & 0.00 & 20.51 & 98.41 \\
BE11-3 & 3.61 & 0.03 & 0.02 & 0.04 & 3.00 & 0.12 & 0.55 & 0.29 & 37.09 & 26.81 & 0.01 & 0.00 & 27.84 & 99.42 \\
BE11S-8 & 11.80 & 0.13 & 0.00 & 0.00 & 0.62 & 0.54 & 1.50 & 0.21 & 44.02 & 18.84 & 0.19 & 0.49 & 20.78 & 99.12 \\
BMPSb-6 & 10.84 & 0.14 & 0.00 & 0.01 & 0.85 & 0.60 & 1.58 & 0.34 & 46.04 & 21.14 & 0.14 & 0.41 & 16.14 & 98.25 \\
BMPSb-10 & 12.81 & 0.14 & 0.01 & 0.00 & 0.65 & 0.55 & 1.39 & 0.23 & 43.10 & 18.97 & 0.20 & 0.39 & 21.05 & 99.49 \\
\hline
\end{tabular}

The molten melt was immediately poured into a 5\% nitric acid solution containing an internal standard andmixed continuously until becoming completely dissolved for about 30 minutes. $0.25 \mathrm{~g}$ sample was digested with acids for trace element analysis, beginning with hydrofluoric acid (HF), followed by a mixture of nitric (HNO3) and perchloric acid $\left(\mathrm{HClO}_{4}\right)$, heated using precise programmer-controlled heating at a temperature range of $6000^{\circ} \mathrm{C}-8000^{\circ} \mathrm{C}$ in several ramping and holding cycles thus drying the samples. After dryness was attained, samples were brought back into solution using hydrochloric acid. The samples were dissociates in an argon plasma and a large number of atomic and ionic spectral lines are excited. The spectral lines are detected by a range of photomultipliers, which were compared with calibration lines, and their intensities converted into concentrations. A suite of trace elements (As, $\mathrm{Ba}, \mathrm{Be}, \mathrm{Cd}, \mathrm{Co}, \mathrm{Cr}, \mathrm{Cu}, \mathrm{La}, \mathrm{Mo}, \mathrm{S}, \mathrm{Ce}, \mathrm{Pb}, \mathrm{Sr}, \mathrm{Y}, \mathrm{V}, \mathrm{Zn}, \mathrm{Ni}, \mathrm{Th}, \mathrm{W}$ and Tl (Table 2) was done using Shimadzu ICPS-7510 sequential, inductively coupled plasma (ICP) spectrometer.

The powder samples for X-ray diffraction (XRD) were analysis were in Tshwane University of Technology Pretoria South Africa. $0.5 \mathrm{~g}$ of powder was mixed with approximately $0.3 \mathrm{~cm}^{3}$ distilled water, pipetted onto a glass slide and allowed to dry. Analysis of specimens took place on a Siemens D5000 diffractometer using a $\mathrm{Cu}$ anode X-ray tube at $40 \mathrm{kV}, 30 \mathrm{~mA}$ and a diffracted-beam graphite monochromator. A step size of $0.04^{\circ}$ and a count time of 4 secs step gave optimum results in terms of time per scan and peak resolution. Samples lignite and argillites were scanned from $2^{\circ} 2 \theta$ to allow analysis of any mixed layer clays. All diffractograms were scaled to give 750 counts for a full-scale peak, using Siemens "Diffrac-At" software. The mineral phases were identified by peak matching using Siemens search/match software. The presence of quartz, pyrite, hematite, kaolinite, illite, feldspar etc. was confirmed through peak breakdown after heating samples for $450^{\circ} \mathrm{C}$ and $550^{\circ} \mathrm{C}$ respectively.

\subsection{Statistical Analysis}

The chemical compositions of lignite and argillite samples are presented in (Table 1 and Table 2). Thirty-one variables were measured, consisting of ten major elements plus loss on ignition (LOI), and twenty-one trace elements. These primary major elements $\left(\mathrm{SiO}_{2}, \mathrm{Al}_{2} \mathrm{O}_{3}, \mathrm{Fe}_{2} \mathrm{O}_{3} \mathrm{MgO}, \mathrm{MnO}, \mathrm{CaO}, \mathrm{TiO}_{2}, \mathrm{Na}_{2} \mathrm{O}, \mathrm{K}_{2} \mathrm{O}\right.$ and $\left.\mathrm{P}_{2} \mathrm{O}_{5}\right)$ and trace elements (As, Be, Cd, Co, Cr, Cu, Mo, Ni, Pb, Se, S, Sr, Th, Ce, Zn, La, Y, Ba, Tl, V, and W) were selected because they are the common and prominent organic and inorganic elements in lignite and argillite, thus appropriate for statistical interpretation. Data obtained from the chemical analysis were subjected to multivariate statistical analysis such as factor analysis (FA) (Table 3(a) and Table 3(b)), principal component analysis (PCA) (Figure 3(a) and Figure 3(b)) and cluster analysis (CA) were done for major and trace elements (Figure 4(a) and Figure 4(b)) using a statistical package for social science (SPSS) software (version 16.0) and Excel. These analyses were applied to the data to avoid misclassification due to the differences in the units of measurements. Standardization tends to increase the influence or variables whose variance is small and reduces the influence of 
Table 2. Trace elements concentration for lignite and argillites from Bali Nyonga (values in parts per million).

\begin{tabular}{|c|c|c|c|c|c|c|c|c|c|c|c|}
\hline Sample \# & As (ppm) & $\mathrm{Ba}(\mathrm{ppm})$ & $\mathrm{Be}(\mathrm{ppm})$ & $\mathrm{Cd}(\mathrm{ppm})$ & $\mathrm{Ce}(\mathrm{ppm})$ & Co (ppm) & $\mathrm{Cr}(\mathrm{ppm})$ & $\mathrm{Cu}(\mathrm{ppm})$ & $\mathrm{La}(\mathrm{ppm})$ & Mo (ppm) & Ni (ppm) \\
\hline BEIIT-2 & 4.1 & 221 & 13.5 & 2.8 & 529 & 10 & 7 & 15 & 406 & 2 & 7 \\
\hline BMPSb-10 & 4.0 & 209 & 2.0 & 4.2 & 253 & 5 & 131 & 22 & 85 & 12 & 25 \\
\hline BEIII-3 & 3.8 & 240 & 9.5 & 2.2 & 655 & 6 & 13 & 20 & 400 & 2 & 9 \\
\hline BEIIT-6 & 4.8 & 218 & 5.5 & 5.4 & 446 & 6 & 1 & 1 & 248 & 3 & 5 \\
\hline BEIIS-8 & 3.8 & 238 & 7.8 & 6.2 & 426 & 6 & 1 & 0 & 287 & 3 & 4 \\
\hline $\mathrm{BN}-3$ & 3.8 & 73 & 2.6 & 2.8 & 381 & 6 & 15 & 12 & 311 & 3 & 7 \\
\hline BMBS-2 & 8.6 & 87 & 2.8 & 4.1 & 667 & 4 & 2 & 4 & 398 & 15 & 5 \\
\hline BMS-2 & 6.2 & 84 & 2.8 & 3.3 & 454 & 9 & 10 & 10 & 352 & 4 & 10 \\
\hline BMBPSb-1 & 5.8 & 67 & 3.0 & 2.2 & 525 & 0 & 3 & 2 & 355 & 3 & 2 \\
\hline BMPSb-6 & 6.9 & 107 & 6.2 & 2.5 & 537 & 4 & 11 & 8 & 592 & 3 & 7 \\
\hline Sample \# & Th (ppm) & $\mathrm{Tl}$ (ppm) & $\mathrm{V}(\mathrm{ppm})$ & W (ppm) & $\mathrm{S}(\mathrm{ppm})$ & $\mathrm{Se}(\mathrm{ppm})$ & $\mathrm{Sr}(\mathrm{ppm})$ & $\mathrm{Pb}(\mathrm{ppm})$ & $\mathrm{Y}$ (ppm) & $\mathrm{P}(\mathrm{ppm})$ & $\mathrm{Zn}(\mathrm{ppm})$ \\
\hline BEIIT-2 & 19 & 17 & 41 & 9 & 2340 & 2 & 58 & 20 & 268 & 240 & 651 \\
\hline BMPSb-10 & 26 & 9 & 226 & 1 & 1182 & 36 & 60 & 24 & 42 & 480 & 75 \\
\hline BEIII-3 & 53 & 21 & 47 & 4 & 2279 & 3 & 48 & 29 & 265 & 409 & 316 \\
\hline BEIIT-6 & 25 & 17 & 22 & 2 & 1582 & 8 & 57 & 19 & 165 & 894 & 238 \\
\hline BEIIS-8 & 5 & 16 & 29 & 2 & 1216 & 8 & 55 & 20 & 168 & 699 & 235 \\
\hline BN-3 & 15 & 13 & 27 & 5 & 1234 & 4 & 42 & 32 & 217 & 201 & 397 \\
\hline BMBS-2 & 43 & 24 & 25 & 18 & 7184 & 5 & 76 & 28 & 198 & 216 & 1354 \\
\hline BMS-2 & 25 & 16 & 21 & 4 & 2445 & 3 & 55 & 31 & 219 & 251 & 191 \\
\hline BMBPSb-1 & 47 & 19 & 4 & 4 & 136 & 5 & 70 & 19 & 164 & 217 & 333 \\
\hline BMPSb-6 & 14 & 17 & 25 & 5 & 935 & 3 & 70 & 26 & 393 & 243 & 292 \\
\hline
\end{tabular}

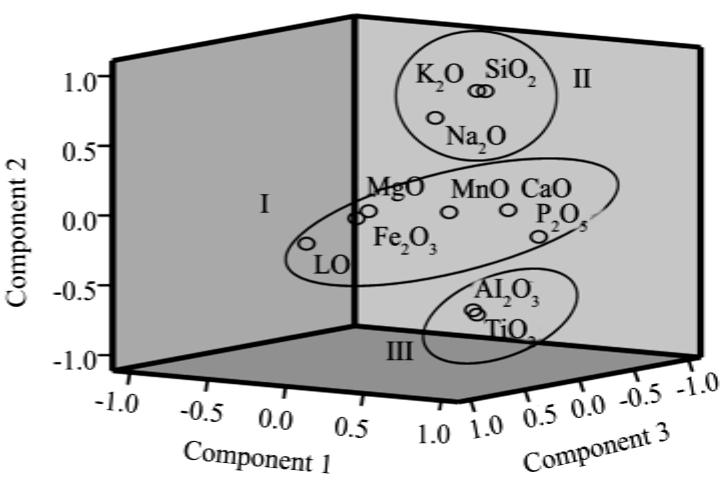

(a)

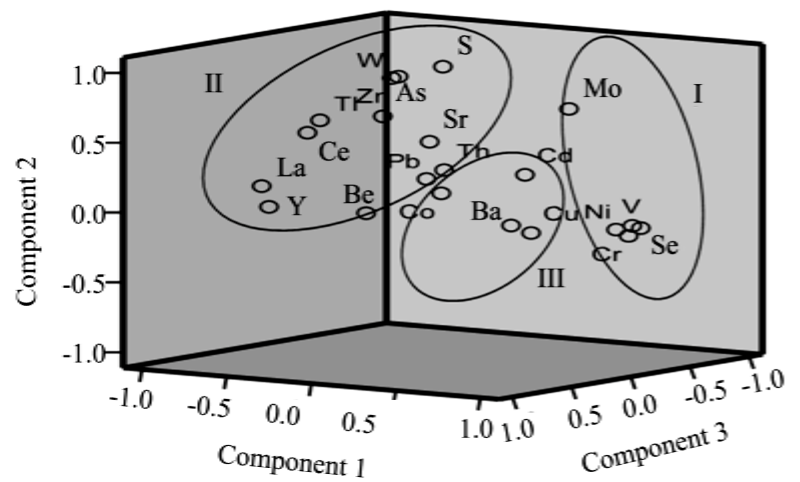

(b)

Figure 3. (a) and (b) Principal Component analysis for the first 3 components for major oxides and trace elements. (a) I represents the lignite and lignitic shale facies, II and III represent claystone facies; (b) I is affiliated to sulphur and iron, and are both epigenetic and syngenetic in origin, II is mostly affiliated to sulphur and silicates and are epigenetic in origin, III have both sulphur and iron affinity and are epigenetic in origin.

variables whose variance is large using [25] procedure. Factor analysis was applied to the data set to study the association of the trace and major elements and extract the principal factors governing trace and major elements 
Table 3. (a) Factor matrix from loading of 10 major elements and LOI on three significant factors. (b) Varimax rotated factor loadings of 21 trace elements on six significant components.

(a)

\begin{tabular}{cccc}
\hline Elements & Factor 1 & Factor 2 & Factor 3 \\
\hline $\mathrm{Al}_{2} \mathrm{O}_{3}$ & 0.111 & -0.780 & -0.452 \\
$\mathrm{CaO}$ & $\underline{0.899}$ & 0.133 & 0.352 \\
$\mathrm{Fe}_{2} \mathrm{O}_{3}$ & 0.311 & 0.094 & $\underline{0.904}$ \\
$\mathrm{~K}_{2} \mathrm{O}$ & 0.413 & $\underline{0.881}$ & -0.055 \\
$\mathrm{LOI}$ & -0.762 & -0.351 & -0.169 \\
$\mathrm{MgO}$ & 0.346 & 0.141 & $\underline{0.842}$ \\
$\mathrm{MnO}$ & $\underline{0.708}$ & 0.137 & 0.620 \\
$\mathrm{Na}_{2} \mathrm{O}$ & 0.338 & $\underline{0.719}$ & 0.220 \\
$\mathrm{P}_{2} \mathrm{O}_{5}$ & $\underline{0.948}$ & -0.084 & 0.142 \\
$\mathrm{SiO}_{2}$ & 0.215 & $\underline{0.807}$ & -0.415 \\
$\mathrm{TiO}_{2}$ & 0.241 & -0.776 & -0.301 \\
\hline
\end{tabular}

(b)

\begin{tabular}{|c|c|c|c|c|c|c|}
\hline Elements & Component 1 & Component 2 & Component 3 & Component4 & Component 5 & Component 6 \\
\hline As & -0.177 & $\underline{0.660}$ & 0.254 & -0.481 & -0.407 & 0.000 \\
\hline $\mathrm{Ba}$ & 0.212 & -0.159 & -0.273 & $\underline{0.890}$ & 0.059 & -0.030 \\
\hline $\mathrm{Be}$ & -0.218 & -0.026 & 0.336 & $\underline{0.902}$ & 0.082 & -0.046 \\
\hline $\mathrm{Cd}$ & -0.052 & 0.107 & -0.768 & 0.212 & -0.151 & -0.494 \\
\hline $\mathrm{Ce}$ & -0.513 & 0.531 & 0.411 & 0.190 & -0.082 & 0.468 \\
\hline Co & 0.044 & 0.105 & 0.077 & 0.462 & 0.664 & -0.449 \\
\hline $\mathrm{Cr}$ & $\underline{0.969}$ & -0.144 & -0.183 & -0.063 & -0.024 & -0.007 \\
\hline $\mathrm{Cu}$ & $\underline{0.743}$ & -0.074 & 0.316 & 0.206 & 0.488 & 0.243 \\
\hline $\mathrm{La}$ & -0.496 & 0.210 & $\underline{0.822}$ & -0.003 & -0.124 & -0.012 \\
\hline Mo & 0.531 & $\underline{0.704}$ & -0.306 & -0.290 & -0.188 & 0.038 \\
\hline $\mathrm{Ni}$ & $\underline{0.966}$ & -0.084 & -0.082 & -0.011 & 0.171 & -0.047 \\
\hline $\mathrm{Pb}$ & 0.121 & 0.250 & 0.311 & -0.506 & $\underline{0.700}$ & 0.069 \\
\hline $\mathrm{S}$ & -0.056 & $\underline{0.980}$ & -0.080 & -0.024 & 0.128 & 0.083 \\
\hline $\mathrm{Se}$ & $\underline{0.873}$ & -0.132 & -0.425 & -0.031 & -0.178 & -0.053 \\
\hline $\mathrm{Sr}$ & 0.033 & 0.485 & 0.158 & -0.179 & -0.827 & 0.040 \\
\hline Th & 0.017 & 0.260 & 0.014 & -0.071 & -0.066 & $\underline{0.945}$ \\
\hline $\mathrm{Tl}$ & -0.600 & 0.579 & 0.180 & 0.118 & -0.168 & 0.452 \\
\hline V & $\underline{0.966}$ & -0.077 & -0.219 & 0.091 & -0.010 & -0.017 \\
\hline W & -0.176 & $\underline{0.924}$ & 0.180 & -0.075 & -0.035 & 0.082 \\
\hline $\mathrm{Y}$ & -0.426 & 0.074 & $\underline{0.859}$ & 0.098 & 0.061 & -0.131 \\
\hline $\mathrm{Zn}$ & -0.223 & $\underline{0.912}$ & 0.056 & -0.025 & -0.064 & 0.114 \\
\hline
\end{tabular}


distribution based on [26] procedure. Cluster analysis (CA) was carried out on the data sets to enable classification being made based on measured "objects" similarity, thereby helping to establish relationships among sites and grouping similar sampling sites spread over the study area in the form of a dendrogram. A comparative statistics such as correlation coefficient for trace and major elements (Table 4(a) and Table 4(b)) was done and since most parameters measured were not normally distributed, Pearson coefficient of correlation was used to examine the correlation between elements (that is, how well each constituent variance can be explained by its relationship to each other).

\section{Results and Discussion}

\subsection{Field Investigation}

Lignite in most locations in the study area occurred in thin to thickly parallel seams alternating with dirt partings of either fine to medium-grained sandstone or clay, ranging in thickness from $0.9 \mathrm{~cm}$ to as thick as $25 \mathrm{~cm}$ (Figure 5(g)) and are greyish brown to dark grey in colour. Some occurred as lenses within claystone and still otherlignite seams contained finely disseminated plant remains embedded in a groundmass of detrital matrix. In other locations like BEII, along a river valley, the lignite seam could measure about $18 \mathrm{~cm}$ in thickness upstream and $28 \mathrm{~cm}$ downstream. The seam had fine-grained sandstone laminae as dirt partings and a lot of wood tissues (xylite) which could be above $35 \%$ of the lignite materials (Figure 5(g)). The abundant carbonized wood (compressed wood), carbonized root and leaf impressions in this seam indicate that the lignite must have been formed from the decomposition of trees and shrubs in the peat forming mire (swamp). The alternation of carbonaceous shale and lignite seams often show features which afford clues to the environment conditions at the time of their

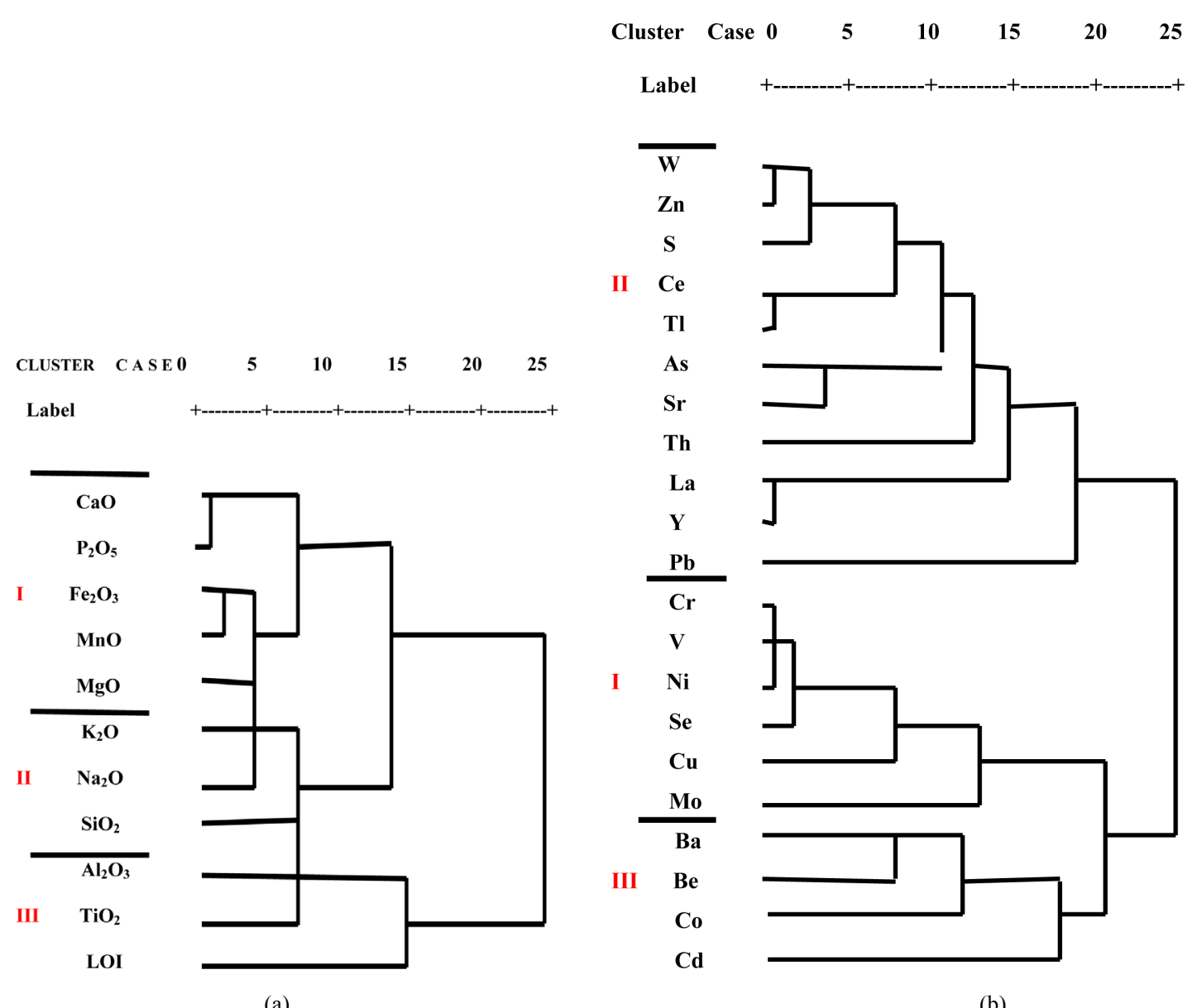

Figure 4. (a) and (b) The result of cluster analysis on the major oxides and trace elements contained in lignite and argillite. 
Table 4. (a) Correlation coefficients between major elements and LOI in lignite and argillite samples; (b) Correlation coefficients of trace elements in lignite and argillite samples.

(a)

\begin{tabular}{|c|c|c|c|c|c|c|c|c|c|c|c|}
\hline & $\mathrm{Fe}_{2} \mathrm{O}_{3}$ & $\mathrm{MnO}$ & $\mathrm{TiO}_{2}$ & $\mathrm{CaO}$ & $\mathrm{K}_{2} \mathrm{O}$ & $\mathrm{P}_{2} \mathrm{O}_{5}$ & $\mathrm{SiO}_{2}$ & $\mathrm{Al}_{2} \mathrm{O}_{3}$ & $\mathrm{MgO}$ & $\mathrm{Na}_{2} \mathrm{O}$ & LOI \% \\
\hline $\mathrm{Fe}_{2} \mathrm{O}_{3} \%$ & 1.000 & & & & & & & & & & \\
\hline $\mathrm{MnO} \%$ & $\underline{0.845}$ & 1.000 & & & & & & & & & \\
\hline $\mathrm{TiO}_{2} \%$ & -0.312 & -0.162 & 1.000 & & & & & & & & \\
\hline $\mathrm{CaO} \%$ & 0.552 & $\underline{0.833}$ & 0.026 & 1.000 & & & & & & & \\
\hline $\mathrm{K}_{2} \mathrm{O} \%$ & 0.191 & 0.437 & -0.601 & 0.437 & 1.000 & & & & & & \\
\hline $\mathrm{P}_{2} \mathrm{O}_{5} \%$ & 0.345 & $\underline{0.714}$ & 0.258 & $\underline{0.951}$ & 0.286 & 1.000 & & & & & \\
\hline $\mathrm{SiO}_{2} \%$ & -0.213 & -0.053 & -0.434 & 0.146 & $\underline{0.766}$ & 0.046 & 1.000 & & & & \\
\hline $\mathrm{Al}_{2} \mathrm{O}_{3} \%$ & -0.372 & -0.235 & 0.593 & -0.220 & -0.566 & 0.048 & -0.441 & 1.000 & & & \\
\hline $\mathrm{MgO} \%$ & $\underline{0.833}$ & $\underline{0.672}$ & -0.216 & $\underline{0.676}$ & 0.130 & 0.480 & -0.067 & -0.513 & 1.000 & & \\
\hline $\mathrm{Na}_{2} \mathrm{O} \%$ & 0.278 & 0.461 & -0.394 & 0.523 & $\underline{0.787}$ & 0.371 & 0.412 & -0.734 & 0.352 & 1.000 & \\
\hline LOI \% & -0.544 & -0.726 & 0.252 & -0.702 & -0.618 & -0.600 & -0.486 & 0.128 & -0.463 & -0.293 & 1.000 \\
\hline
\end{tabular}

(b)

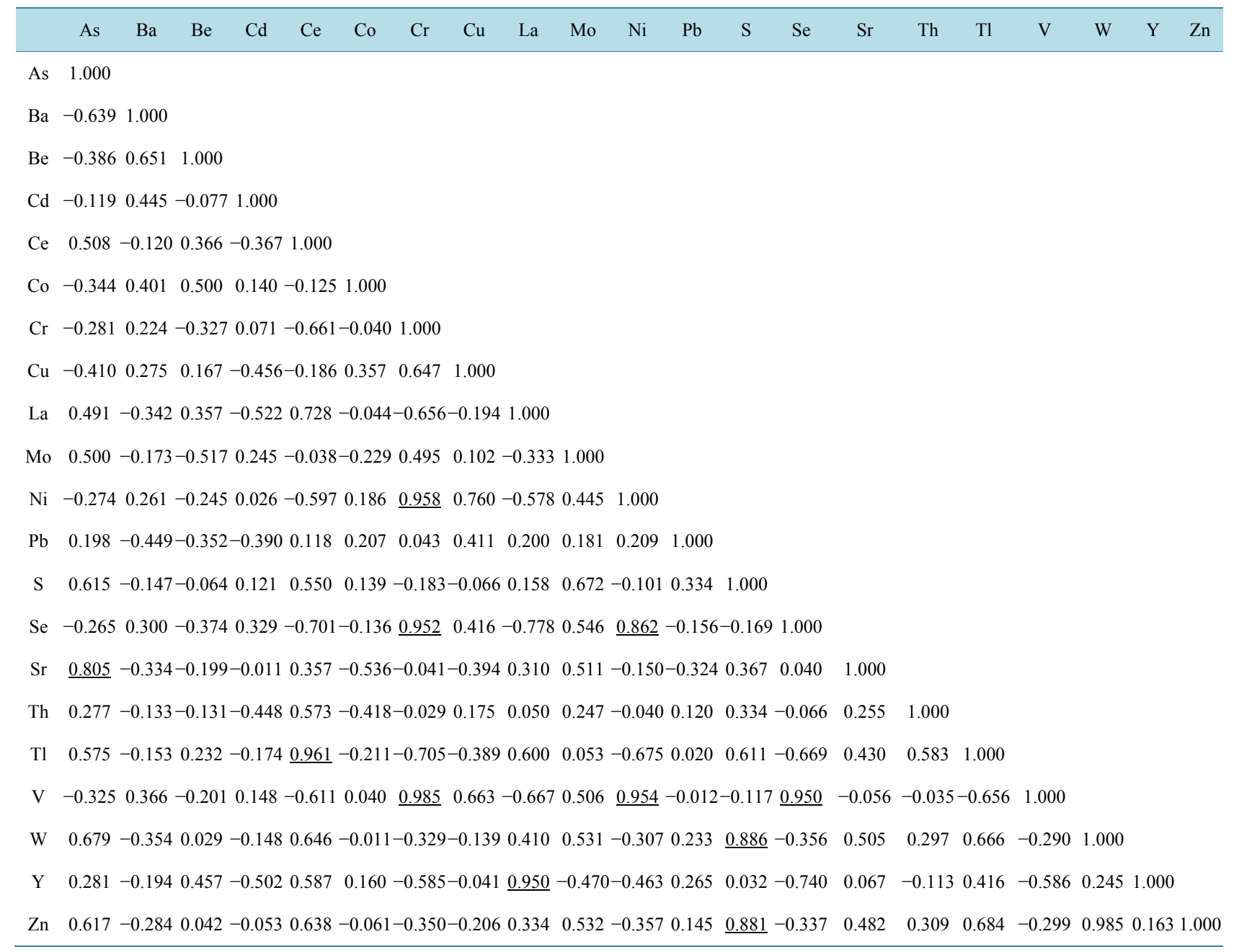


accumulation. Dark gray to black argillite (carbonaceous shale) with significant amount of vegetal materials in the form of disseminated particles or flakes occurred as laminae and dirt partings in most of the lignite seams in this area; and in some locations, they were found embedded as fragmental clasts within fine to medium-grained volcanic ash.

A common feature observed on the field is the splitting of lignite seams through rhythmic deposition in sequence, especially conspicuous in samples (Figure 5(a) and Figure 5(b)) from localities such as Boh Etoma II Trench (BEIIT), Boh Muyangka Pit (BMP) and Boh Muyangka-Banda Pit (BMBP). Thin lignite seams were
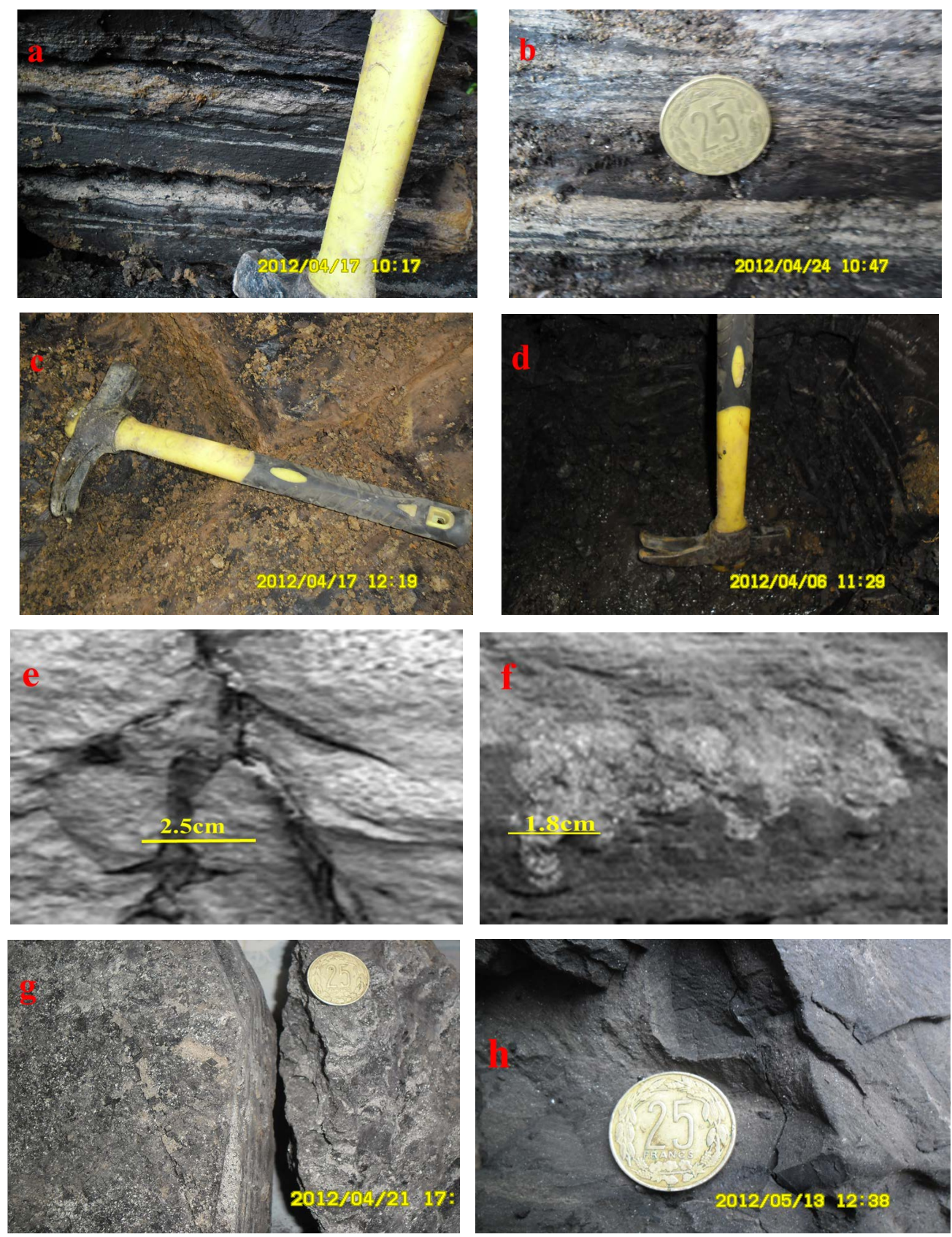

Figure 5. (a)-(h) illustrates (a) and (b) rhythmic laminated lignite with dirt partings of fine-grained sandstone; (c) polygonal desiccation cracks filled with reddish brown medium-grained pelitic sandstone, forming Neptunian dykes; (d) thick lignite seam with fine volcanic ash parting; (e) vertical, in-situ carbonized plant roots in volcano-carbonaceous shale bed; (f) highly burrowed carbonaceous shale with burrow-infilling by upper bioturbated pelitic sandstone bed; $(\mathrm{g})$ and $(\mathrm{h})$ lignite samples with woody tissues (xylite) and cleat in filled with clay. 
seen interrupted by dirt partings in this basin, in locations such as BEIIT, BMP, and BMBP. A seam when trace vertically along the trench or pit, splits in to several thinner seams and lenses separated by sediment partings such as fine to medium-grained sandstone and more common are claystone from altered volcanic ash/tuffs. This splitting reflects the instability of the basin of deposition, with the deposition of volcanic air-fall deposits (ash/tuffs) over part of the basin and the cessation of plant growth during its presence. It may also suggest a temporal change in the physical conditions, perhaps a temporal flooding with sediment-laden water in a shallow quiet water environment protected from intense wave agitation and abundant volcanic ash fall deposits [18]. The lignite itself may represent a period during which growth and accumulation of vegetation was continuous. These lignite seams are succeeded by argillite sediments indicative of a sudden influx of argillaceous matter and organic debris, probably caused by a subsidence of the basin with deeper inshore water occurring. These argillaceous sediment series is followed by another in which fine-grained sandstone and volcanic ash are abundant. This probably represents a period of uplift of the margins of the basin, in which circumstance; the incoming streams would have greater erosive and carrying powers to bring into the basin fine to medium-grained sediments.

The common interlayering of carbonaceous shale facies of BMP with sandstone, and volcanogenic sediments and complete churning of the upper portion of the interface of the sediments by burrowing organisms (Figure $5(f)$ ) is indicative of low-rate sedimentation in a quiet-water environment. The fine to medium-grained, probably bioturbated sandstone bed represents an infrequent incursion of storms into deeper water environment that was otherwise characterized by settlement of suspension sediments (fine mud and organic debris). This upper pelitic sandstone bed may have been emplaced by low water storms on the inner deep water mud. The burrows vary in diameter from a few millimeters to about $24 \mathrm{~mm}$ with some being vertical, horizontal or u-shaped. The burrowfilling are made up of medium-grained pelitic sandstone and minor pellets. The organic debris was supplied with required nutrients and oxygen; and as such, this facies horizon became an initial site for burrowing activity. Another major feature in this facies is the occurrence of a vertical to sub-vertical carbonized plant roots, that show a downward branching pattern and the root diameter varies from less than $4 \mathrm{~mm}$ to about $4 \mathrm{~cm}$ and the length of the roots ranges from about $8 \mathrm{~mm}$ to about $27.7 \mathrm{~cm}$.

A sequence of lignite seams and argillite beds in BEIIT had polygonal desiccation cracks of varying dimensions, averagely $64 \mathrm{~cm}$ in depth. These cracks are filled with the overlying greyish brown fine-grained pelitic sandstone, forming a neptunean dykes. This regular pattern of the desiccation cracks (Figure 5(c)) and the isolated nature of their occurrences in the BEII facies probably suggest a sub-aqueous origin [27].

The volcanic ash fall that occurred as dirt parting in the lignite seams, were intensively altered to claystone; were from pyroclastic current that emanate from the surrounding calderas such as the Santa-Mbu caldera, $(6 \mathrm{~km}$ by $4 \mathrm{~km}$ ), the Lefo caldera ( $4 \mathrm{~km}$ by $3 \mathrm{~km}$ ), and the Bamboutos caldera [20]. The sandstone layers gradually coarse-up the basin with the deposition of a layer of medium to coarse-grained volcanic tuffs/breccia (Figure 6(a)-(d)). The facies association of Boh Etoma II (BEII) represents an intermountain low lying environment with high precipitation and sediment run-off, rimmed by piedmont alluvial fan which has suffered periodic emergence and plant colonization and their sedimentology has a shallow coarsening-upward succession of facies (Figure 6(c)). This type of sedimentary succession rarely occurs, except perhaps in proximal portions of very small lakes or swamps [28]. A map of the study area with lithology logs tagged on the corresponding trench and pits (Figure 6(d)), shows the various sequences of the lignite and argillite in these locations.

The deeper water interpretation for the facies unit in BMP is further supported by the absence of plant roots, desiccation features that are common in the lignite beds of the Boh Etoma II (BEII) facies and the upper portion of Boh Muyangka (BM) facies unit. The fine-grained size of rocks in BMP and BMBP lithologic units indicates deep water environments [29]. The presence of carbonized compressed log or wood, abundant leaf and bark impressions especially on the bedding surfaces of carbonaceous shale beds, and the dark grey to black nature or colour of the pyritised carbonaceous shale, claystone beds of these facies units (BM and Boh Muyangka Banda (BMB)) suggest a poorly-oxygenated (reducing or anoxic) depositional environmental condition characterized by standing water bodies, deeper bottom environment and below fair-weather wave base that could have periodically be churned by gravity storm waves. This facies unit represent the distal part of the depositional basin. Also observed where clasts of dark brown to dark grey lignite embeded in fine to medium-grained volcanic ash. These fragmental clasts vary in diameter from less than $0.28 \mathrm{~cm}$ to as large as $7 \mathrm{~cm}$ and are randomly distributed within the volcanic ash, with some been sub-rounded to rounded and others angular to sub-angular in shape (Figure 7(b)). 


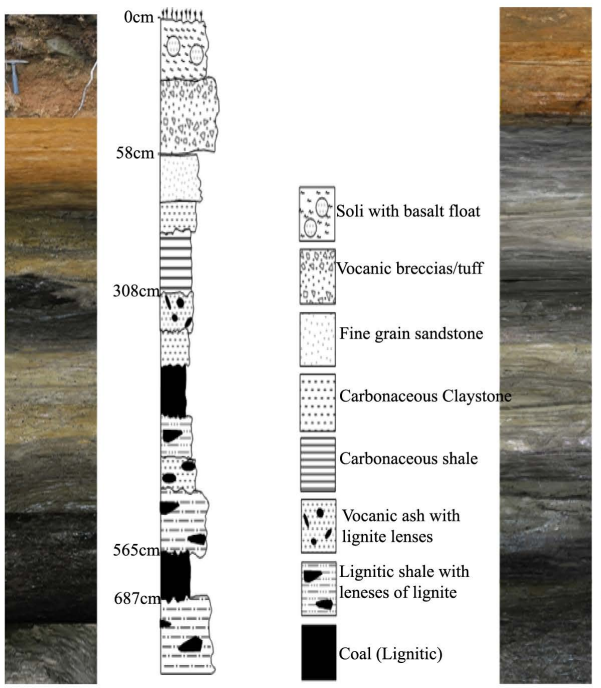

(a)
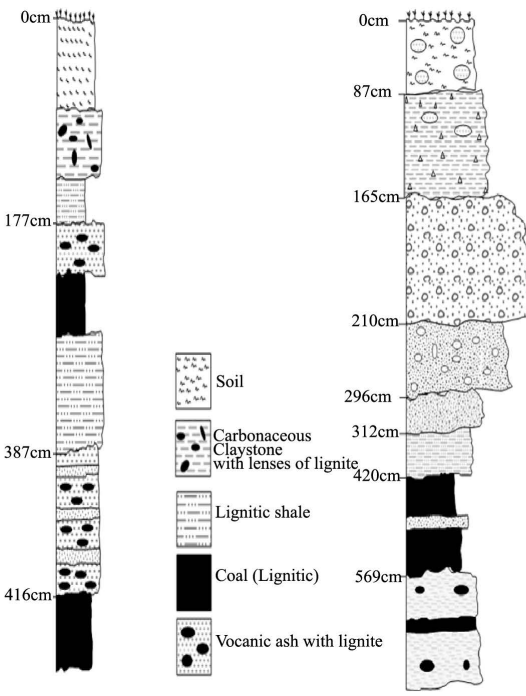

(b)

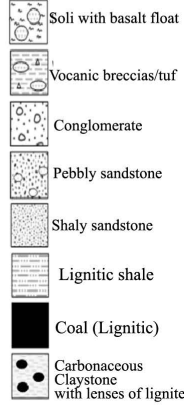

(c)

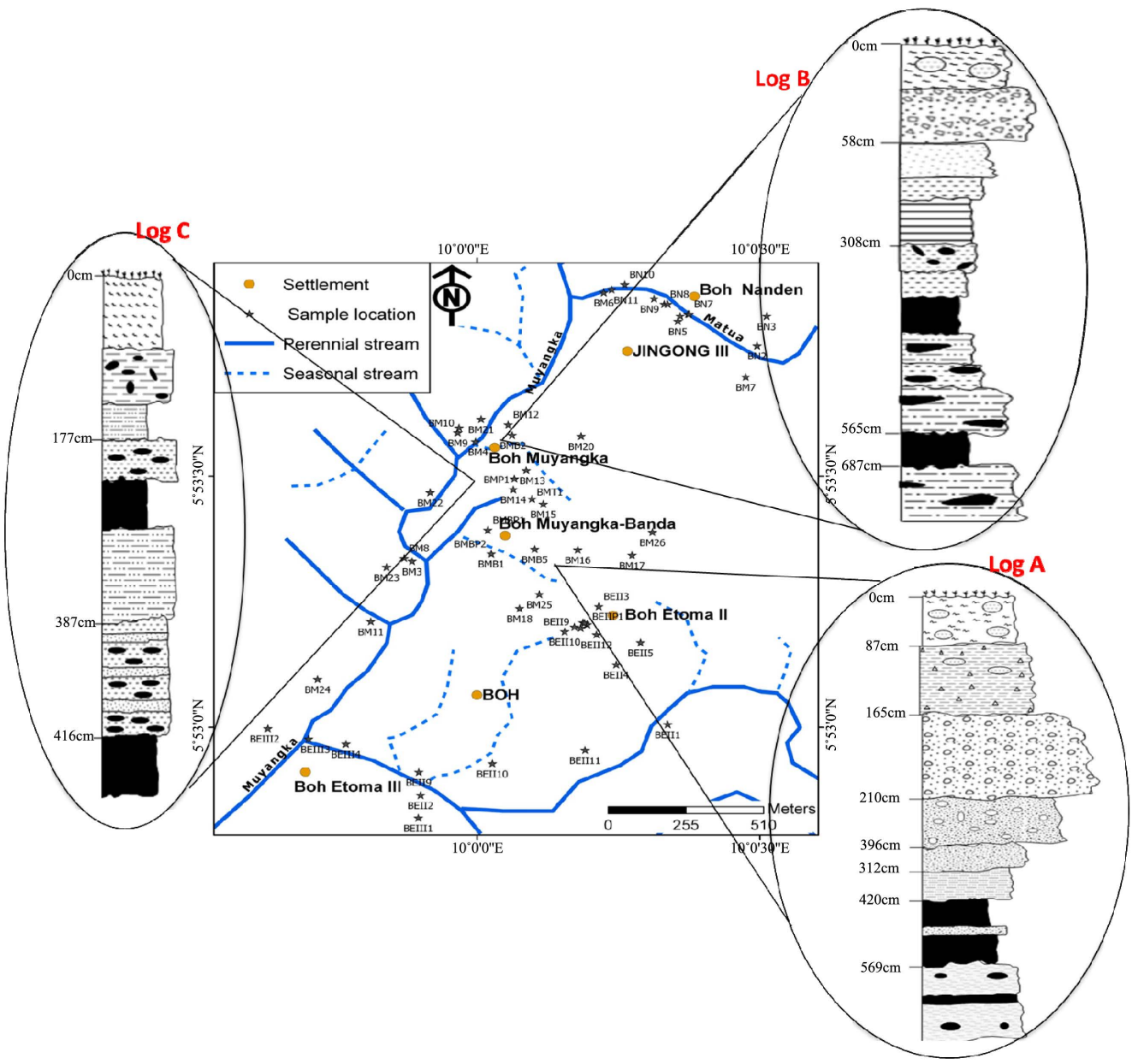

(d)

Figure 6. (a)-(d) Lithostratigraphic logs illustrating lignite-argillite sequences (a) Boh Muyangka Pit (BMP); (b) Boh Muyangka-Banda Pit (BMBP) and (c) Boh Etoma II Trench (BEIIT) showing a shallow coarsening-upward lithostratigraphic sequence $(d)$ the position of lignite seams in the pits and trench in the study area; [logA] Boh Etoma II Trench in the South east, [ $\log$ B] Boh Muyangka Pit and [ $\log C]$ Boh Muyangka-Banda Pit. B and C are both in the Northern part of the basin. 

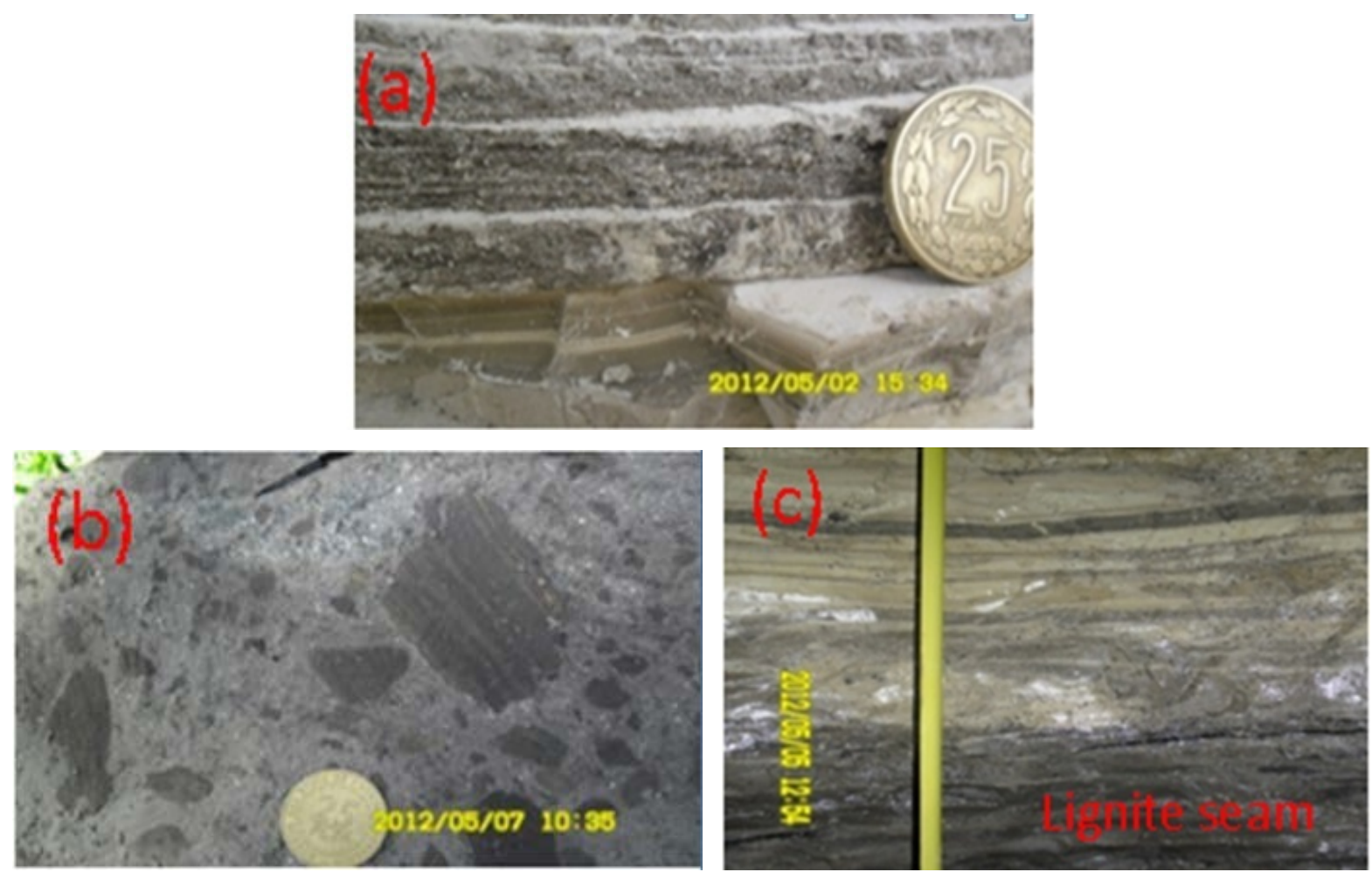

Figure 7. (a)-(c) illustrates (a) lignite seams alternating with altered fine to medium-grained volcanic ash laminae; (b) fragmental clasts of dark brown to dark grey lignite embeded in fine to medium-grained volcanic ash; (c) clayey microbands with mixed-layers clay minerals, interlayered with organic bands, carbonaceous shales and lignite seams.

Clayey microbands derived from alkaline volcanic ashes were identified in the lignite. The dominant compositions of these clayey microbands were mixed-layer clay minerals of illite and kaolinte, which were interlayered with organic bands.Lignite seams alternating with altered fine to medium-grained volcanic ash/claystone laminae (Figure 7(a)). In some locations, some of the claystoneoccurs as separate beds within lignite-bearing sequences, and also as thin but often persistent bands within individual lignite seams (Figure 7(b)). The modes of occurrence of alkaline volcanic ash bands indicate that the volcanic activities were characterized by multiple eruptions, short time interval and of small scale for each eruption during peat accumulation (Figure 7(c)).

\subsection{Mineral Composition of the Lignite and Argillite}

X-ray diffractograms from lignite and argillite samples from various localities are shown in (Figure 8). All six selected representive samples show at least four prominent peaks with $2 \theta$ angles for the maximum intensity peaks for lignite samples at $31.9^{\circ}$ and $25.1^{\circ}$ for kaolinite, $12.3^{\circ}$ for quartz, $28.5^{\circ}$ for pyrite in Boh Muyangka sample (BMPsb.10), and Boh Muyangka Banda sample (BMBPsb.1). At 11.6 $6^{\circ}, 31.9^{\circ}$ for kaolinite, 21.2 ${ }^{\circ}, 27.6^{\circ}$ for quartz and $26.5^{\circ}$ for hematite in all Boh Etoma II samples (BEIIT.6 and BEIIS.8). For argillite samples, $31.9^{\circ}$ for kaolinite, $26.5^{\circ}$ and $27.1^{\circ}$ for quartz, $25^{\circ}$ for pyrite in Boh Muyangka and Boh Muyangka Banda samples (BMPsb.6 and BMBS.2). This study shows that these samples contained relatively higher mineral contents, indicating much abundant detrital supply during peat accumulation. Authigenic kaolinite $(\mathrm{K})$, illite $(\mathrm{I})$, and quartz $(\mathrm{Q})$ are the main detrital minerals in addition to authigenic pyrite $(\mathrm{P})$, hematite $(\mathrm{H})$, that are present with minor contents in the samples analysed. A significant proportion of detrital minerals was found in the basal parts (BM and BMB) and near the margins (BEII and BEIII) of this peat swamp forming basin of Bali. These authigenic kaolinite and illite are likely to have been derived through tropical weathering under a somewhat acidic condition, which are completely volcanically-derived materials such as tuffs/ashes and brecciated rhyolites, rich in feldspars and other aluminosilicates. The detrital quartz in the analysed samples might have been derived from the weathering of the basement complex and acid alkaline volcanic igneous rocks, which crops out in the southeast, west and northern parts of this basin, and transported by water flowing towards this swamp 

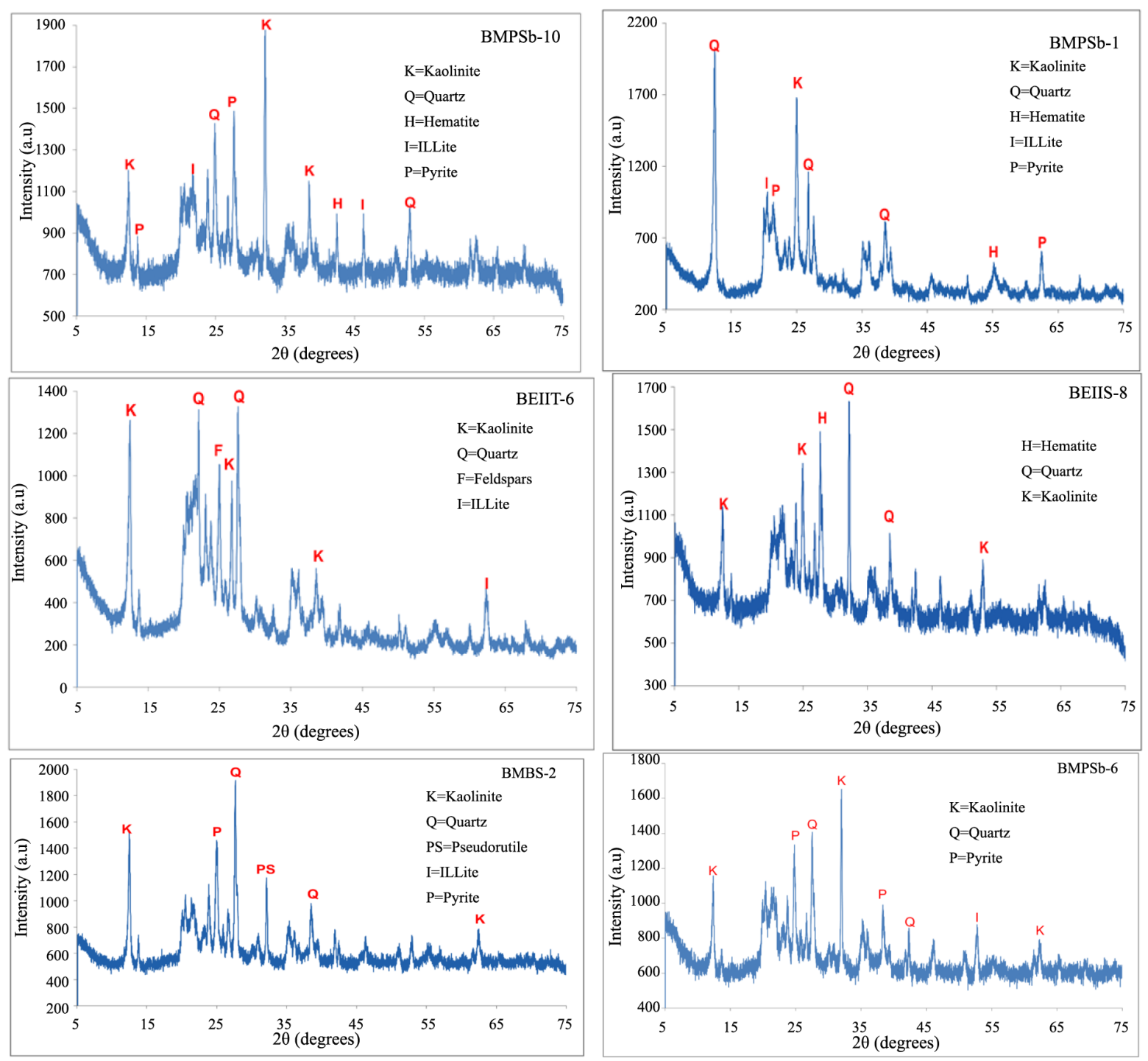

Figure 8. X-ray diffractogram (Peak intensity (a.u) versus $2 \theta$ (degree) angle) of mineral phases in lignite and argillite samples in the Bali Basin, with the letters on the peaks represented by: K: kaolinite; Q: quartz; I: illite; P: pyrite; H: hematite; F: feldspars; PS: pseudorutile.

margin. Some quartz might have been introduced to the peat by mixing of the silica-rich water with the volcanic sediments already existing on the swamp floor in the basin. The mixing of peat and swamp floor sediment may have arisen somehow from a combination of bioturbation by organisms and contemporaneous clastic deposition early in the history of peat accumulation. Some detrital particles may also have been blown by winds into the swamp, including air-borne material of pyroclastic origin which may penetrate more extensively into the peat-forming environment. Such materials may include wide spread deposits of altered volcanic tuffs/ash such as koalinite, illite, quartz and feldspars. Others minerals in the lignite and argillite samples may occur as biogenic mineral particles such as amorphous silica that are relatively soluble in water, that may result directly from biological activity in the peat swamp (including skeletal fragments from diatoms, molluscs and other organisms). Some from minerals formed within living plant tissues, and others possibly deposited in the peat swamp as faecal pellets.

\subsection{Elemental Geochemistry}

A total of 10 samples were analysed for a whole suite of elements, in which ten (10) major elements and twenty 
one (21) trace elements were selected and are reported here and a complete geochemical data for the suite of trace elements can be obtained from the author. The geochemical data are summarised in (Table 1 and Table 2).

\subsubsection{Major Element Geochemistry}

The moderately high concentration of $\mathrm{SiO}_{2}(37.09-54.10 \mathrm{wt} \%), \mathrm{Al}_{2} \mathrm{O}_{3}(18.83-27.77 \mathrm{wt} \%)$, and $\mathrm{Fe}_{2} \mathrm{O}_{3}(1.13-$ $12.81 \mathrm{wt} \%$ ), is due to quartz, feldspar, clay minerals, and pyrite that constitutes the main mineral phase in the lignite and argillite samples. The high concentrations of $\mathrm{SiO}_{2}(>51 \mathrm{wt} \%)$, and $\mathrm{Al}_{2} \mathrm{O}_{3}$ content $(>25 \mathrm{wt} \%)$ compared with the concentrations of other major elements in the analysed samples, suggest a high detrital input from the surrounding of the basin during peat formation. This quartz-rich lignite of Bali-Nyonga occurs beneath intra-seam ash and claystone bands apparently of pyroclastic origin, with the possibility that the quartz may represent silica released by the complete alteration of volcanic glass, feldspars and other minerals in the pyroclastic sediments, due to interaction of the tuff/ ash with the water of the peat swamp environment [30]. The relatively low concentration of $\mathrm{CaO}(0.12-1.94 \mathrm{wt} \%)$ and $\mathrm{MgO}(0.00-0.20 \mathrm{wt} \%)$ in the analysed samples implied a continental origin for the lignite [31]; and this agreed very much with the continental setting of the study area. The strong positive factor loading and relationship between these gruop of oxides: $\mathrm{MgO}, \mathrm{MnO}, \mathrm{Fe}_{2} \mathrm{O}_{3}, \mathrm{CaO}_{2} \mathrm{P}_{2} \mathrm{O}_{5}$ and $\mathrm{K}_{2} \mathrm{O}, \mathrm{SiO}_{2}, \mathrm{Na}_{2} \mathrm{O}$ suggests a common detritial source for these group of elements and the weak positive correlation coefficient between $\mathrm{TiO}_{2}$ and $\mathrm{Al}_{2} \mathrm{O}_{3}(\mathrm{r}=0.593)$ is typical of elements that probably came from weathering of surrounding alkaline acid igneous rocks.

Studies of major elements through factor analysis provided vital statistical information on the grouping of the elements and the processes responsible for their formation. The first factor shows a high positive loading for $\mathrm{CaO}, \mathrm{MnO}, \mathrm{P}_{2} \mathrm{O}_{5}$, suggesting input from carbonate-phosphate rich sources. Factor two showed a high positive loading for $\mathrm{K}_{2} \mathrm{O}, \mathrm{Na}_{2} \mathrm{O}, \mathrm{SiO}_{2}$ and a high negative loading for $\mathrm{Al}_{2} \mathrm{O}_{3}$ and $\mathrm{TiO}_{2}$, and the oxides of $\mathrm{Si}, \mathrm{Al}, \mathrm{K}, \mathrm{Na}$ and Ti represent minerals phases such as quartz, feldspar, clay, rutile which are common detrital minerals in the lignite [32]; and this reflected sediments believed to have their source probably from the weathering of alkaline rich volcanic rocks in the Northeast and Southwestern flanks of the basin. Factor 3 indicates a strong positive loading for $\mathrm{Fe}_{2} \mathrm{O}_{3}$ and $\mathrm{MgO}$ and this indicates the weathering of the basic volcanic rocks in the area of study. Factor one and three have an organic association based on their relatively high concentration in the lignite and carbonaceous (lignitic) shale facies in the study area. The strong positive loading of $\mathrm{K}_{2} \mathrm{O}, \mathrm{SiO}_{2}$, and $\mathrm{Na}_{2} \mathrm{O}$ in factor two represents detrital inorganic minerals inputs that have high affinity for clay and are bound to the claystone facies.

Cluster I, (Figure 4(a)) consisted of oxides ( $\left.\mathrm{CaO}, \mathrm{MgO}, \mathrm{MnO}, \mathrm{Fe}_{2} \mathrm{O}_{3}, \mathrm{P}_{2} \mathrm{O}_{5}\right)$ associated with organic matter and they are organically bound to carbonate-phosphate rich sediments. The iron availability may have been associated with the transport of organic colloids or clay into the basin [33]. Cluster 2 represented by $\mathrm{K}_{2} \mathrm{O}, \mathrm{Na}_{2} \mathrm{O}$, $\mathrm{SiO}_{2}$, reflects detrital sources probably from feldspar rich acid volcanic rocks and basement complex [34]. Cluster $3\left(\mathrm{Al}_{2} \mathrm{O}_{3}, \mathrm{TiO}_{2}\right.$ and $\left.\mathrm{LOI}\right)$ are typical due to the occurrence kaolinite and feldspars derived from alteration of volcanic air-fall deposits and clastic inputs. The cluster pair between $\mathrm{Al}_{2} \mathrm{O}_{3}$ and LOI indicates that most of the volatile in the analyzed samples were mineral moisture held in the crystal structure of hydrous silicates such as clay.

\subsubsection{Trace Element Geochemistry}

The poor correlation of sulphur $(\mathrm{S})$ with $\mathrm{Cu}(\mathrm{r}=0.158), \mathrm{Cd}(\mathrm{r}=0.121), \mathrm{Pb}(\mathrm{r}=0.334), \mathrm{Sr}(\mathrm{r}=0.04), \mathrm{Y}(\mathrm{r}=$ $0.032), \mathrm{Be}(\mathrm{r}=-0.064), \mathrm{V}(\mathrm{r}=-0.117), \mathrm{Co}(\mathrm{r}=0.139), \mathrm{Cr}(\mathrm{r}=-0.183)$, Ni $(\mathrm{r}=-0.101)$; indicates that the sulphur was not only present in its sulphide form but also in organic form [2]. There is a high significant correlation $(r=0.805-0.985)$ between elements in the following groups: As and Sr, S and W, S and Zn, Ni and Se, La and $\mathrm{Y}, \mathrm{Cr}$ and $\mathrm{Ni}, \mathrm{Cr}$ and $\mathrm{Se}, \mathrm{Ni}$ and $\mathrm{V}, \mathrm{W}$ and $\mathrm{Zn}$, Se and V, thallium (Tl) and cerium (Ce). These elements are essentially associated with inorganic detrital minerals, sulphides and clay minerals [8]. Although there is a high correlation coefficient between the pairs, $\mathrm{Ni}$ and $\mathrm{Cr}(\mathrm{r}=0.958), \mathrm{Cr}$ and $\mathrm{V}(\mathrm{r}=0.985)$, $\mathrm{Ni}$ and $\mathrm{V}(\mathrm{r}=0.954), \mathrm{Ni}$ and $\mathrm{Cu}(\mathrm{r}=0.760)$, and $\mathrm{V}$ and $\mathrm{Se}(\mathrm{r}=0.950)$, they show a negative trend in the lignite and argillite facies on the bivariate correlation plot of the analyzed samples (Figures 9(a)-(d)). The negative trends are indicative of mixing of two sedimentary components from different sources [35], in which, Ni is inoganically associated and has a sulphide affinity while $\mathrm{Cr}$ is totally having an inorganic association and on the other hand, $\mathrm{Zn}$ has an inorganic association and probably from sulphides and $\mathrm{S}$ is organically bound and has both a sulphide and sulphate affinity [36]. [2] suggested that $\mathrm{Cr}$ and $\mathrm{Ni}, \mathrm{Cr}$ and V, Ni and V, shows a mafic source, but [37]-[39] indicated that Ni, V, 


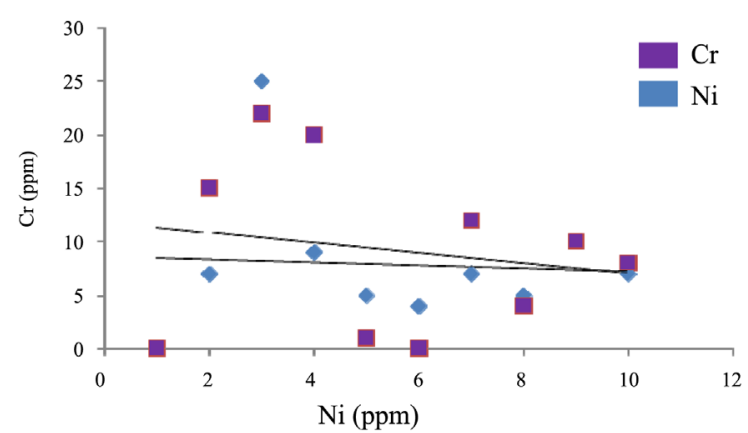

(a)

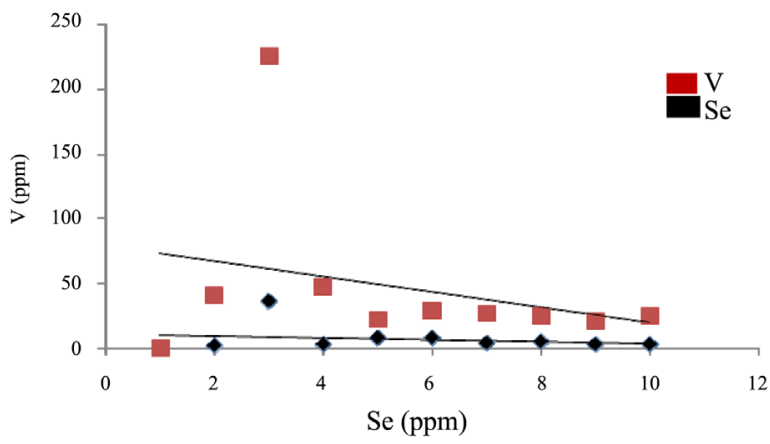

(c)

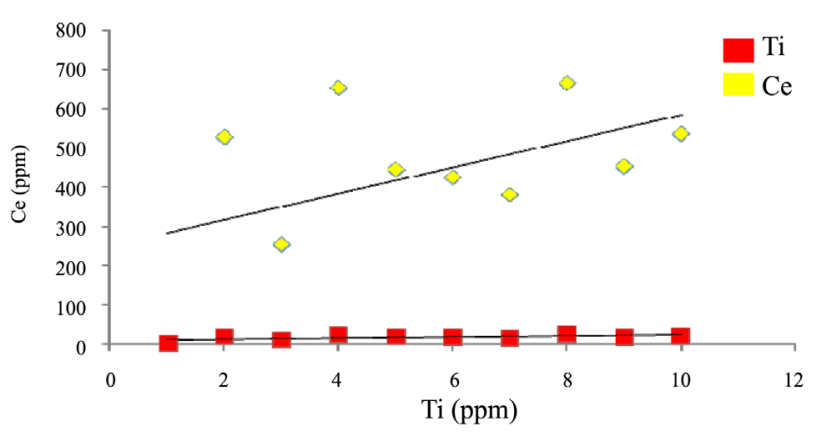

(e)

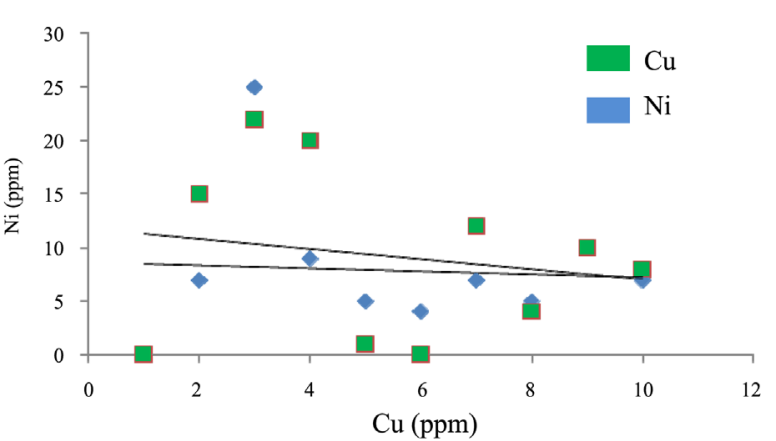

(b)

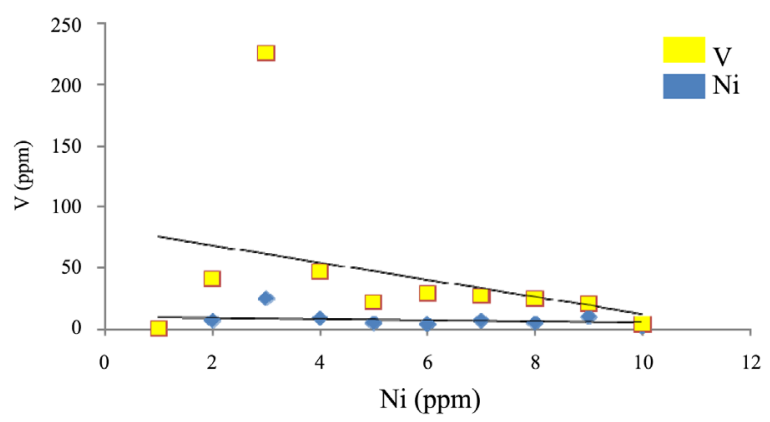

(d)

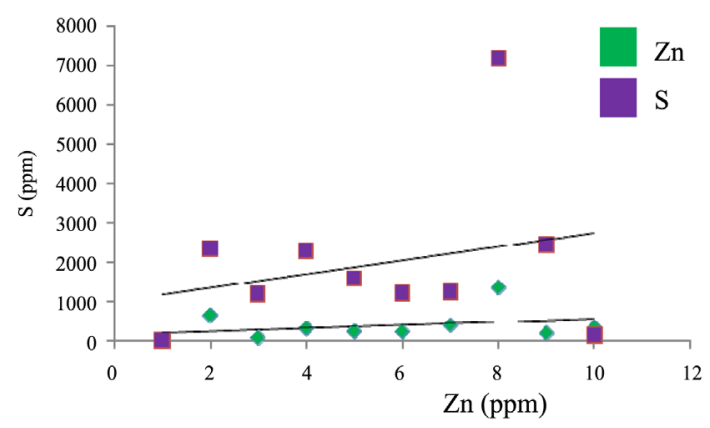

(f)

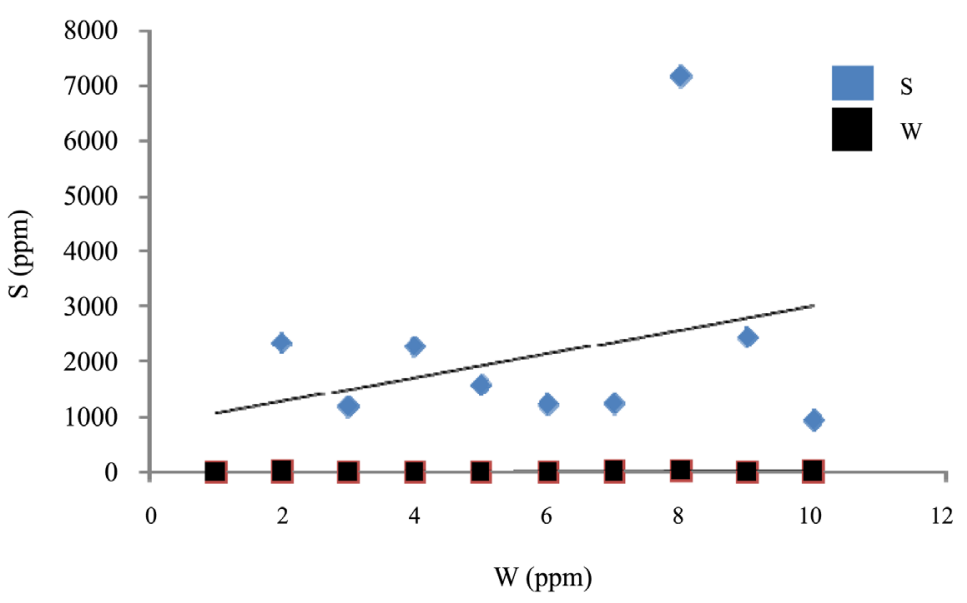

(g)

Figure 9. Bivariate correlation plot for trace elements in selected lignite and argillite samples (a)-(d) show a negative trend; (e)-(g) show a positive trend for the elements. 


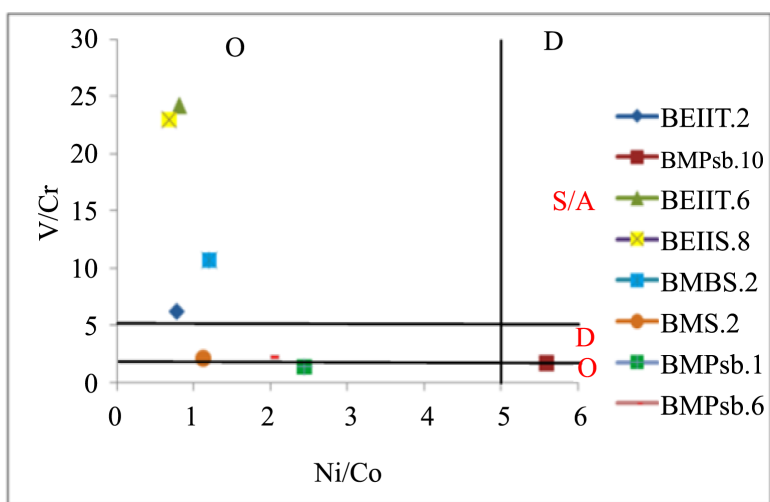

(a)

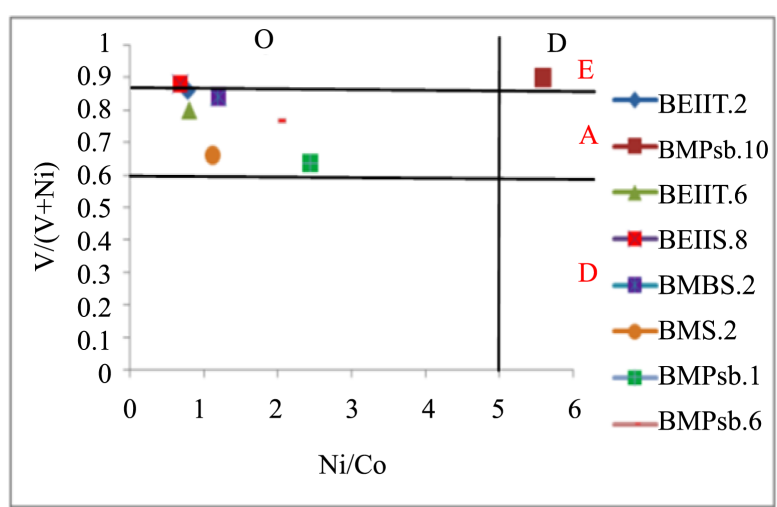

(b)

Figure 10. (a)-(b) Cross plots of redox-sensitive trace element ratios from Bali lignite and argillite samples: (a) $\mathrm{V} / \mathrm{Cr}$ vs $\mathrm{Ni} / \mathrm{Co}$; ranges after $[13]$ (b) $\mathrm{V} /(\mathrm{V}+\mathrm{Ni})$ vs. $\mathrm{Ni} / \mathrm{Co}$; ranges after [12]/Where $\mathrm{O}=$ Oxic, $\mathrm{D}=$ Dysoxic, $\mathrm{S} / \mathrm{A}=\mathrm{Suboxic} / \mathrm{Anoxic}$, $\mathrm{A}=$ Anoxic, and $\mathrm{E}=$ Euxinic Environments.

and $\mathrm{Cu}$ have a sulphide affinity and are organically associated because they may be extracted from the soil by photosynthesising plant for their biological needs and they are easily mobilised in the soils and aqueous environment. Figures $9(\mathrm{e})-(\mathrm{g})$ illustrate positive trends and therefore indicate that these elements are from the same source and have a sulphide affinity.

The principal component 1 (PC1) showed a positive loading for $\mathrm{Cr}, \mathrm{Cu}, \mathrm{Ni}, \mathrm{Se}, \mathrm{V}$, Mo (Figure 3(b)) and the inferred host phases of minerals for $\mathrm{PC} 1$ are a mixture of lithophilic $(\mathrm{Mo} ; \mathrm{r}=0.704)$, siderophilic $(\mathrm{Cr}, \mathrm{V}, \mathrm{Ni} ; \mathrm{r}=$ $0.966-0.969)$ and chalcophilic elements $(\mathrm{Cu}, \mathrm{Se}, \mathrm{Tl} ; \mathrm{r}=0.743-0.966)$. Principal component 2 (PC2) had positive loadings for $\mathrm{As}, \mathrm{Ce}, \mathrm{Pb}, \mathrm{La}, \mathrm{Th}, \mathrm{Sr}, \mathrm{Y}, \mathrm{S}, \mathrm{Ti}, \mathrm{Zn}$, and W; and to [2], $\mathrm{La}, \mathrm{Th}, \mathrm{Ce}, \mathrm{Y}, \mathrm{Sr}$, are lithophilic elements associated with aluminosilicate mineralsand have a detrital inorganic association except $\mathrm{Sr}$ that has a high organic and carbonate affiliation, Th and $\mathrm{La}$ are detrital inorganic elements and are indicative of felsic igneous sources [40]. Arsenic (As), S, $\mathrm{Pb}$ andZn have an association with sulphides and are therefore have high affinity forthe chalcophiles [36]. PC3 showed a positive loading for $\mathrm{Co}, \mathrm{Cd}, \mathrm{Ba}$ and $\mathrm{Be} . \mathrm{Be}$ is a lithosphilic element. Cd (chalcophilic) and Co (siderophilic) both have an inorganic association [2]. [41] studied the geochemistry of coal and overlying strata and concluded that high-sulfur coal is also enriched in Mo, Fe, Tl. The concentration of $\mathrm{Tl}$, and Mo are derived from terrigenous sources by weathering and were transported to the swamp by rivers andincorporated in pyrite during early diagenesis of peat in a sulphur-rich and reducing environment. Components four and five have an organic affinity and are bound to the lignite and carbonaceous (lignitic) shale facies while components $1,2,3$ and 6 , are detrital inorganic fractions of the mineral matter and are associated elements to the claystone facies.

Cluster 1 (Figure 4(b)) consisted of elements (Cr, V, Ni, Se, Cu, Mo) indicating a strong association with sulphides such as Pyrite $\left(\mathrm{FeS}_{2}\right)$, chalcopyrite $\left(\mathrm{CuFeS}_{2}\right)$, molybdenite $\left(\mathrm{MoS}_{2}\right)$. [42] had studied the association of trace elements and found that $\mathrm{Cu}$ and $\mathrm{Ni}$ can originate from both organic and inorganic sources. Cluster 2 consisted of elements associated with detrital input (Ce, La Sr, Th, Y,) and sulphide affinity (W, Zn, S, Tl, As, Pb). The detrital input sources for these trace elements are commonly represented by terrigenous inorganic constituents. Cluster 2 also shows sulphide affinity. [43] indicated that iron-sulphides deposited directly in carbonaceous rocks (coal) in the form of segregations are strongly enriched in thallium (Tl) and it is often absent from the claystone which are free of sulphides and it is also associated with $\mathrm{Pb}$ and $\mathrm{Bi}$ in brown coal, can be interpulaed with the samples from BEII Trench. These sulphide-rich minerals in the study area may indicate the occurrence of a syngenitic metallic sulphide. Cluster 3 represent a mixture of elements affiliated to $\mathrm{Be}, \mathrm{Co}, \mathrm{Ba}$ and $\mathrm{Cd}$. These chalcophilic (Co and $\mathrm{Cd}$ ) elements possibly occurred as epigenetic sulphides which represent remobilization of organic sulphur or syngenetic sulphides within the lignite [44]. Cluster 1 and 3 show a positive clustering and this represent a common source for the elements.

\subsection{Use of Geochemical Data in Environmental Discrimination of Lignite-Argillite Sequences}

Redox-sensitive trace element ratio $(\mathrm{Ni} / \mathrm{Co}, \mathrm{V} / \mathrm{Cr}$ and $\mathrm{V} /(\mathrm{V}+\mathrm{Ni})$ presented in the cross-box (Figure 10(a) and 
Figure 10(b)) are usually considered powerful geochemical indicators for environmental discrimination. [13] suggested that $<5 \mathrm{Ni} / \mathrm{Co}$ ratio inferred oxic conditions, $5-7$ dysoxic conditions and $>7$ suboxic to anoxic conditions. They also used $<2 \mathrm{~V} / \mathrm{Cr}$ ratio to infer oxic conditions, $2.0-4.25$ for dysoxic conditions and $>4.25$ for suboxic to anoxic conditions [45]; [12] showed that $\mathrm{V} /(\mathrm{V}+\mathrm{Ni})$ should be greater than 0.5 for organic matter accumulated in euxinic conditions. [46] pointed out that $\mathrm{SiO}_{2}$ and $\mathrm{Al}_{2} \mathrm{O}_{3}$ contents can be used as indicators of terrestrial-prone depositional environment. They also proposed that $\left(\mathrm{CaO}+\mathrm{MgO}+\mathrm{Fe}_{2} \mathrm{O}_{3}\right) /\left(\mathrm{SiO}_{2}+\mathrm{Al}_{2} \mathrm{O}_{3}\right)$ ratios higher or lower than 0.22 indicates a strong or weak reductive depositional environment for coal respesctively. [47] further discuss how the ratio of $\mathrm{Sr}$ /Bacould be used as indicators of a depositional environment. According to them, $\mathrm{Sr} / \mathrm{Ba}$ ratios $0.1 \approx 0.6 ; 0.7 \approx 1.2 ; 1.3 \approx 1.6$, implied terrestrial, littoral to brackish water and marine depositional environments respectively. All the samples analysed and shown on the $\mathrm{V} / \mathrm{Cr} \mathrm{vs}$. $\mathrm{Ni} / \mathrm{Co}$ and $\mathrm{V} / \mathrm{V}+\mathrm{Ni}$ vs. Ni/Co, diagram (Figure 10(b)) plotted within the oxic ranges for the four redox-sensitive traceelement ratios as stated by [13].

\section{Conclusions}

The sedimentology and geochemical characteristics of the lignite and argillite sequences within a Basin in Bali Nyonga, West of the Bamenda Mountain were investigated, and their lithological sequences together with the prevailing environmental conditions which controlled their formation were determined. Clayey microbands derived from alkaline volcanic ashes were identified in lignite and were examined to be mixed-layered clay minerals interbedded with organic bands, and their modes of occurrence indicated that the volcanic activities that deposited them were characterized by multiple eruptions, short time interval and small scale for each eruption during peat accumulation. The organic matter for the formation of the lignite deposits in Bali Nyonga, accumulated in place and this therefore indicates an autochthonous (growth in place) lignite deposit.

The weathering of alkaline volcanic ash/tuffs, mafic and felsic igneous rocks was considered to be the dominant factor for the enrichment of detrital inorganic input fraction, and this reflects the geology of the surrounding rocks to a high degree. The relatively high silica $(54.10 \mathrm{wt} \%)$ and alumina contents $(27.77 \mathrm{wt} \%)$ in these samples indicate a high detrital input during peat formation. The low contents of $\mathrm{MgO}$ and $\mathrm{CaO}$ on the other hand agree very much with the continental setting of the peat forming basin. The main mineral phases contained in the lignite and argillites were quartz, pyrite, hematite, aluminosilicate or clay minerals (kaolinite and illite), feldspar, and minor phase of pseudorutile. The study also reveals that trace elements such as $\mathrm{Co}, \mathrm{Pb}, \mathrm{As}, \mathrm{Se}, \mathrm{Ni}$, $\mathrm{Cu}$, and $\mathrm{Zn}$ have sulfide affinity and that the aluminosilicate and sulphide minerals might have been responsible for the occurrence and distribution of most trace elements in the lignite and argillites of Bali Nyonga.

Elements' geochemical associations were examined through principal component analysis (PCA), factor analysis (FA), cluster (CA) and statistical correlation of major and trace elements. Factors 1 and 3 for major oxides are bound to the organic rich facies and factor 2 consists of clastic rock-derived elements which are bound to clay facies. The PCA for trace elements corresponds to the cluster groups with the first and third groups consisting of elements having a high sulfide affinity, and second group consisting mainly of clastic rock-derived elements with some of the elements having a high affinity for sulfides, and elements of these groups are either epigenetic or syngenetic in origin.

The ratios of environmental redox-sensitive elements (trace elements, $\mathrm{Sr} / \mathrm{Ba}$, and $\left(\mathrm{CaO}+\mathrm{MgO}+\mathrm{Fe}_{2} \mathrm{O}_{3}\right) /$ $\left.\left(\mathrm{SiO}_{2}+\mathrm{Al}_{2} \mathrm{O}_{3}\right)\right)$ analysed from the Bali Nyonga lignites and argillites samples indicate a terrestrial and littoralbrackish water reducing environmental conditions which are characteristics of paludal-lacustrine basin that is filled by Tertiary volcanic materials.

\section{Acknowledgements}

This article is part of a M.Sc. thesis on sedimentology and geochemistry of lignite-argillite by the author. We are grateful for the support and contributions from the Department of Geology and Chemistry in the University of Buea. I also appreciate Dr. Mbom Divine and Dr. Che Vivian for their assistance in this research. The editorial comments of the editor are highly appreciated.

\section{References}

[1] Orem, W.H. and Finkelman, R.B. (2003) Coal Formation and Geochemistry. In: Mackenzie, F.T., Ed., Sediments, Diagenesis, and Sedimentary Rocks: Treatise on Geochemistry, Volume 7, Elsevier-Pergamon, Oxford, 191-222. 
http://dx.doi.org/10.1016/b0-08-043751-6/07097-3

[2] Finkelman, R.B. (1995) Modes of Occurrence of Environmentally-Sensitive Trace Elements in Coal. In: Swaine, D.J. and Goodarzi, F., Eds., Environmental Aspects of Trace Elements of Coal, Kluwer Academic Publishers, Dordrecht, 24-50.

[3] McCabe, P.J. (1984) Depositional Environment of Coal and Coal-Bearing Strata. In: Rahmani, R.A. and Flores, R.M., Eds., Sedimentology of Coal and Coal-Bearing Sequences, Volume 7, International Association of Sedimentologists, Special Publication, Blackwell Publishers, Oxford, 13-42.

[4] Raymond Jr., R., Cladney, E.S., Bish, D.L., Cohens, A.D. and Maestas, L.M. (1990) Variation of Inorganic Content of Peat with Depositional and Ecological Setting. In: Chyi, L.L. and Chou, C.L., Eds., Recent Advance in Coal Geochemistry, Geological Society of America Special Paper 248, 1-12.

[5] Christanis, K., Georgakopoulos, A., Fernandez-Turiel, J.L. and Bouzinos, A. (1998) Geological Factors Influencing the Concentration of Trace Elements in the Philippi Peatland, Eastern Macedonian, Greece. International Journal of Coal Geology, 36, 295-313. http://dx.doi.org/10.1016/S0166-5162(98)00004-4

[6] Swaine, D.J. (1990) Trace Elements in Coal. Butterworth and Co. (Publishers) Ltd., London, 278 p.

[7] Finkelman, R.B. (1994) Modes of Occurrence of Potentially Hazardous Elements in Coals: Levels of Confidence. Fuel Processing Technology, 29, 21-34. http://dx.doi.org/10.1016/0378-3820(94)90169-4

[8] Spears, D.A. and Zheng, Y. (1999) Geochemistry and Origin of Elements in Some UK Coals. International Journal of Coal Geology, 38, 161-179. http://dx.doi.org/10.1016/S0166-5162(98)00012-3

[9] Vassilev, S.V., Eskenazy, G.M. and Vassileva, C.G. (2001) Behaviour of Elements and Minerals during Preparation and Combustion of the Pemikcoal, Bulgaria. Fuel Processing Technology, 72, 103-129. http://dx.doi.org/10.1016/S0378-3820(01)00186-2

[10] Davis, A., Russell, S.J., Rimmer, S.M. and Yeakel, J.D. (1984) Some Genetic Implications of Silica and Aluminosilicates in Peat and Coal. International Journal of Coal Geology, 3, 293-314.

[11] Andrejko, M.J., Raymond Jr., R. and Cohen, A.D. (1983) Mineral Matter in Peat: Its Occurrence, Form, and Distribution. In: Raymond Jr., R. and Andrejko, M.J., Eds., Proceedings of the Workshop, Los Alamos National Labs, Los Alamos, 25-37.

[12] Hatch, J.R. and Leventhal, J.S. (1992) Relationship between Inferred Redox Potential of the Depositional Environment and Geochemistry of the Upper Pennsylvanian (Missourian) Stark Shale Member of the Dennis Limestone, Wabaunsee Country, Kansas, USA. Chemical Geology, 99, 65-82.

[13] Jones, B. and Manning, D.A.C. (1994) Comparison of Geochemical Indices Used for the Interpretation of Palaeoredox Conditions in Ancient Mudstones. Chemical Geology, 111, 111-129. http://dx.doi.org/10.1016/0009-2541(94)90085-X

[14] Adedosu, T.A., Adedosu, H.O. and Adebiyi, F.M. (2007) Geochemical and Mineralogical Significance of Trace Metals in Benue Trough Coals, Nigeria. Journal of Applied Sciences, 7, 3101-3105. http://dx.doi.org/10.3923/jas.2007.3101.3105

[15] Njonfang, E., Nono, A., Kamgang, P., Ngako, V. and Tchoua, M.F. (2011) Cameroon Line Alkaline Magmatism (Central Africa): A Reappraisal. The Geological Society of America Special Paper, 478, 173-189.

[16] Marzoli, A., Piccirillo, E.M., Renne, P.R., Bellieni, G., Iacumin, M., Nyobe, J.B. and Tongwa, A.T. (2000) The Cameroon Volcanic Line Revisited: Petrogenesis of Continental Basaltic Magma from Lithospheric and Asthenospheric Mantle Sources. Oxford University Press, Oxford, 87-109.

[17] Nono, A., Njongfang, E., Kagou, D.A., Nkouathio, D. and Tchoua, F.M. (2004) Pyroclastic Deposits of the Bambouto Volcano (Cameroon Line, Central Africa): Evidence of a Strombolian Initial Phase. Journal of African Earth Sciences, 39, 409-414. http://dx.doi.org/10.1016/j.jafrearsci.2004.07.026

[18] Gountie Dedzo, M., Nedelec, A., Nono, T., Njanko, T., Font, E. and Kamgang, P. (2011) Magnetic Fabrics of the Miocene Ignimbrites from West-Cameroon: Implications for Pyroclastic Flow Source and Sedimentation. Journal of Volcanology and Geothermal Research, 203, 113-132.

[19] Kamgang, P., Njonfang, E., Chazot, G. and Tchoua, F. (2007) Géochimie et géochronologie des laves felsiques des monts Bamenda (ligne volcanique du Cameroun). Comptes Rendus Geoscience, 339, 659-666. http://dx.doi.org/10.1016/j.crte.2007.07.011

[20] Tchoua, F.M. (1973) Existence of an Ignimbritic Phase in the Volcanism of Mount Bamboutos (Cameroon). Comptes rendus de l'Académie des Sciences, 276, 2863-2866.

[21] Dumort, J.C. (1964) Notice explicatif sur la Feuille de Douala Quest. Ministère de mines, Yaoundé, 20-22.

[22] Kenfack, P.L. (2002) Données sédimentologiques préliminaires sur les sédiments intercalés entre les niveaux pyro- 
clastiques de Ngwa. Mém. Maît. Sci. Terre. Univ. Dschang, 44.

[23] Kwekam, M. (2005) Genèse et évolution des granitoïdes calco-alcalins au cours de la tectonique Panafricaine: Le cas des massifs syn-à tardi-tectoniques de l'Ouest-Cameroun (Régions de Dschang et de Kekem). Thèse Doctorat d'Etat. Université de Yaoundé I, Yaoundé, 194.

[24] Wilson, R.C. (1928) The Geology of Eastern Railway. Section I. Port Harcourt to Enugu and the Gulf of MamfeCameroon. Brown coal in Nigeria. Bulletin of Geological Survey of Nigeria, 13-86.

[25] Liu, C.W., Lin, K.H. and Kuo, Y.M. (2003) Application of Factor Analysis in the Assessment of Groundwater Quality in Blackfoot Disease Are in Taiwan. Science of the Total Environment, 313, 77-89.

[26] Lu, X., Zeng, H., Xu, T. and Yan, R. (1995) Chemometric Studies of Distribution of Trace Elements in Seven Chinese Coals. Fuel, 74, 1382-1386. http://dx.doi.org/10.1016/0016-2361(95)00077-I

[27] Collinson, J.D. (1996) Alluvial Sediments. In: Reading, H.G., Ed., Sedimentary Environments: Processes, Facies and Stratigraphy, 3rd Edition, Blackwell Science, Oxford, 37-81.

[28] Picard, M.D. and High Jr., L.R. (1972) Criteria for Recognizing Lacustrine Rocks. In: Rigby, J.K. and Hamblin, W.K., Eds., Recognition of Ancient Sedimentary Environments, Society of Economic Paleontologists and Mineralogists Special Publication No. 16, 108-145.

[29] Talbot, M.R. and Allen, P.A. (1996) Lakes. In: Reading, H.G., Ed., Sedimentary Environments: Processes, Facies and Stratigraphy, 3rd Edition, Blackwell Science, Oxford, 83-124.

[30] Ward, C.R., Crouch, A. and Cohen, D.R. (1997) Identification of Frictional Ignition Potential for Rocks in Australian Coal Mines. In: Doyle, R., Moloney, J., Rogis, J. and Sheldon, M., Eds., Safety in Mines: The Role of Geology, Coalfield Geology Council of New South Wales, Newcastle, 169-175.

[31] Olobaniyi, S.B. and Ogala, J.E. (2011) Major and Trace Element Characteristics of the Tertiary Lignite Series within the Ogwashi-Asaba Formation, Southern Nigeria. Proceedings of the 23rd Colloquium of Africa Geology/14th Conference of the Geological Society of Africa, Johannesburg, 8-14 January 2011, 323.

[32] Vassilev, S.V. and Vassileva, C.G. (1996) Occurrence, Abundance and Origin of Minerals in Coal Ashes. Fuel Processing Technology, 48, 85-106. http://dx.doi.org/10.1016/S0378-3820(96)01021-1

[33] Cohen, A.D., Spackman, W. and Dolsen, P. (1983) Mineral Matter in Peat: Its Occurrence, Form and Distribution. In: Raymond Jr., R. and Andrejko, M.J., Eds., Proceedings of the Workshop, Los Alamos National Labs, Los Alamos, 87112.

[34] Elueze, A.A., Ekwere, A.S. and Nton, M.E. (2009) Geo-Environmental Assessment of the Environs of the Aluminum Smelting Company in Ikot Abasi, South Eastern Nigeria. Journal of Mining and Geology, 45, 115-128.

[35] Norman, M.D. and De Deckker, P. (1990) Trace Metals in Lacustrine and Marine Sediments: A Case Study from the Gulf of Carpentaria, Northern Australia. Chemical Geology, 82, 299-318. http://dx.doi.org/10.1016/0009-2541(90)90087-N

[36] Kleesattel, D.R. (1984) Distribution, Abundance, and Maceral Content of the Lithotypes of the Beulah-Zap Bed of North Dakota. Proceedings of the Rocky Mountain Coal Symposium, Bismarck, ND, 2 October 1984.

[37] Bowan, H.J.M. (1966) Trace Element in Biochemistry. Academic Press, London.

[38] Dulka, J.J. and Riisby, T.H. (1976) Ultratrace Metals in Some Environmental and Biological Systems. Analytical Chemistry, 48, 640A-633A. http://dx.doi.org/10.1021/ac50002a711

[39] Reeves, R.D. and Brooks, R.R. (1978) Trace Element Analysis of Geological Mateials. John Wiley and Sons, New York, P341-P373.

[40] McLennan, S.M. and Taylor, S.R. (1991) Sedimentary Rocks and Crustal Evolution Revisited: Tectonic Setting and Secular Trends. The Journal of Geology, 9, 1-21. http://dx.doi.org/10.1086/629470

[41] Chou, C.L. (1984) Relationship between Geochemistry of Coal and the Nature of Strata Overlying the Herrin Coal in the Illionois Basin, USA. Memoir of the Geological Society of China, No. 6, 269-280.

[42] Pareek, H.S. and Bardhan, B. (1985) Trace Elements and Their Variation along Seam Profiles of Certain Coal Seams of Middle and Upper Barakar Formations (Lower Permian) in East Bokaro Coalfield, District Hazaribagh, Bihar, India. International Journal of Coal Geology, 5, 281-314. http://dx.doi.org/10.1016/0166-5162(85)90030-8

[43] Voskresenskaja, N.T., Timofeyewa, N.V. and Topkhana, M. (1962) Thallium in Some Minerals and Ores of Sedimentary Origin. Geochemistry, 8, 851-857.

[44] Demchuk, T.D. (1992) Epigenetic Pyrite in a Low-Sulphur, Sub-Bituminous Coal from the Central Alberta Plains. International Journal of Coal Geology, 21, 187-196. http://dx.doi.org/10.1016/0166-5162(92)90023-P

[45] Lewan, M.D. (1984) Factors Controlling the Proportionality of Vanadium to Nickel in Crude Oils. Geochimica et Cosmochimica Acta, 48, 2231-2238. http://dx.doi.org/10.1016/0016-7037(84)90219-9 
[46] Chao, S.C., Tong, M.S. and Wang, F.Y. (1994) Model Discussions of Environment-Type-Characteristics of Coalification (I) Environment and Facies of Deposition. Journal Sed., 12, 32-39. (In Chinese)

[47] Tang, Y.G., Ren, D.Y., Liu, C.F., Yao, F.H. and Gam, C.J. (1996) Relationships between Sulfur Content and Coalification Environment of the Late Permian Coal in Sichuan. Journal of Sed., 14, 161-167. (In Chinese) 